\title{
Pathogenic Biohacking: Induction, Modulation and Subversion of Host Transcriptional Responses by Listeria monocytogenes
}

\author{
Matthew J. G. Eldridge ${ }^{1,2}$, Pascale Cossart ${ }^{2}$ and Mélanie A. Hamon ${ }^{1, *}$ \\ 1 Chromatine et Infection G5, Institut Pasteur, 75015 Paris, France; matthew.eldridge@pasteur.fr \\ 2 Unité des Interactions Bactéries-Cellules, Institut Pasteur, 75015 Paris, France; pascale.cossart@pasteur.fr \\ * Correspondence: melanie.hamon@pasteur.fr
}

Received: 15 April 2020; Accepted: 3 May 2020; Published: 5 May 2020

\begin{abstract}
During infection, the foodborne bacterial pathogen Listeria monocytogenes dynamically influences the gene expression profile of host cells. Infection-induced transcriptional changes are a typical feature of the host-response to bacteria and contribute to the activation of protective genes such as inflammatory cytokines. However, by using specialized virulence factors, bacterial pathogens can target signaling pathways, transcription factors, and epigenetic mechanisms to alter host gene expression, thereby reprogramming the response to infection. Therefore, the transcriptional profile that is established in the host is delicately balanced between antibacterial responses and pathogenesis, where any change in host gene expression might significantly influence the outcome of infection. In this review, we discuss the known transcriptional and epigenetic processes that are engaged during Listeria monocytogenes infection, the virulence factors that can remodel them, and the impact these processes have on the outcome of infection.
\end{abstract}

Keywords: gene expression; transcription factor; epigenetics; Listeria; virulence factor

Key Contribution: In this review we provide a global view of the host transcriptional response to Listeria monocytogenes infection and the mechanisms used by the pathogen to alter gene expression to its own advantage.

\section{Introduction}

Regulation of gene expression at the transcriptional level is fundamental in enabling a cell to enact transient or permanent phenotypic changes. Through the actions of intricate networks of receptors and signaling cascades, cells integrate external signals into a transcriptional response in order to adapt to environmental stimuli. Signal transduction pathways relay information to distinct transcriptional and epigenetic regulators, that ensure the necessary alterations in gene expression. Given its importance, transcription is tightly regulated at multiple levels by transcription factors and chromatin modifiers. Chromatin is a complex of DNA and protein and plays an important role in organizing the genetic material of the cell. The primary structural component of chromatin is the nucleosome, which consists of DNA wrapped around a protein octamer comprising of core histones H2A, H2B, H3, and H4 [1]. Chromatin modifiers such as histone-modifying enzymes, and chromatin-remodeling enzymes, regulate the accessibility of DNA to transcription factors and the transcriptional machinery. Therefore, chromatin modifications are essential for signal transduction integration into a transcriptional response, as they control whether a gene is held in an active or silent state [1,2].

Post-translational modification (PTM) of histones can regulate the transcriptional permissiveness of chromatin by inducing direct structural alterations, or recruiting additional chromatin-regulating 
factors $[3,4]$. Among the most well-defined modifications are acetylation, phosphorylation and methylation, which occur on histone N-terminal tails and select residues in the globular domain [5]. Histone acetylation and phosphorylation promote transcription by disrupting the electrostatic interactions between histones and DNA, thereby relaxing chromatin structure and making DNA more accessible to transcription factors. On the contrary, the absence or removal of such modifications can have the opposing effect, causing chromatin compaction and transcriptional repression $[3,6]$. In addition to a structural role, histone modifications also act as binding platforms to facilitate or block recruitment of other chromatin-regulating proteins [7-10], including transcription factors [11-13], chromatin remodeling enzymes [13], histone/DNA-modifying enzymes [13,14], or protein complex adaptors [13,15]. Histone modifications are often dynamic and, in some cases, only occur transiently to promote the transcription of particular genes. However, certain repressive histone marks recruit proteins such as heterochromatin protein 1 (HP1), which holds chromatin in its condensed and silent configuration, and has more stable, long lasting effects $[7,16,17]$. Gene regulators, such as transcription factors and epigenetic processes, work concurrently to ensure appropriate and robust transcriptional regulation in response to environmental stimuli and stress, such as bacteria.

The bacterium Listeria monocytogenes $(\mathrm{Lm})$ is a well-established model organism in the study of host-pathogen interactions and has been used extensively to examine host transcriptional responses to infection [18-24]. Lm is a foodborne, facultative intracellular pathogen and causative agent of listeriosis, which typically manifests as febrile, self-limiting gastroenteritis [24]. However, $L m$ can also cross cellular barriers to cause systemic disease, which can be fatal in immunocompromised individuals, and cause dangerous prenatal infections in pregnant women. $L m$ is transmitted orally, usually via contaminated food, and enters the gastrointestinal tract where it invades and replicates within epithelial cells [25]. During systemic infection, $L m$ breaches the intestinal barrier, enters the bloodstream and disseminates to secondary infection sites such as the liver and spleen. Because of its ability to invade non-phagocytic cells, $L m$ can also cross endothelial barriers, such as the blood-brain barrier or placenta, causing sepsis, meningitis, or miscarriage.

During infection, $\mathrm{Lm}$ comes into contact with many different tissues and cell types, and therefore causes widespread changes to the gene expression profile of its host, both at a cellular [18-21], and whole organism level [22,23]. Lm is detected by multiple families of pattern recognition receptor (PRR), including the nucleotide-binding domain and leucine-rich repeat (NLR) proteins, and toll-like receptors (TLRs), which respectively localize to the cytoplasm and cellular membranes. These receptors play a crucial role in generating the transcriptional response to $L m$ by signaling to transcription factors such as nuclear factor- $\mathrm{KB}(\mathrm{NF}-\mathrm{kB})[26]$, which regulates the expression of hundreds of genes important for inflammatory and immune responses [27-29]. Later stages of infection are also characterized by the activation of additional signaling cascades leading to global changes in transcriptional regulation of the host [18-22,26]. In addition to the transcriptional response that follows the detection of bacteria, $\mathrm{Lm}$ also actively reprograms the host response with virulence factors thereby promoting its own ability to survive and cause disease [30-34]. In this review, we will focus on the transcriptional and epigenetic changes that arise upon sensing $L m$ during infection, the mechanisms used by $L m$ to influence these events, and how these illustrate the complex signaling crosstalk that takes place during infection.

\section{Host-Driven Antimicrobial Inflammatory Responses}

Transcriptional responses to $L m$ infection include the induction of two broad categories of gene expression profiles: one dominated by NF- $\mathrm{BB}$ and Mitogen-activated protein kinase (MAPK)-regulated inflammatory genes; and another composed of interferon-stimulated genes (ISGs) [24,29,35].

\subsection{NF- $\kappa B$ and MAP Kinase-Regulated Transcriptional Profile}

NLR/TLR signaling to $L m$ infection primarily occurs in response to the detection of conserved microbe-associated molecular patterns (MAMPs) such as bacterial cell wall components. The NLRs NOD1 and NOD2 detect diaminopimelic acid (DAP) and muramyl dipeptide (MDP), respectively [29]; 
and TLR2, which forms heterodimers with TLR1, TLR6, or TLR10, and recognizes bacterial lipoproteins (LP), and lipoteichoic acids (LTA) [36,37]. TLR5, which detects bacterial flagella proteins, also responds to $L m$ derived flagellin [38]. However, because $L m$ suppresses flagella production at $37{ }^{\circ} \mathrm{C}$, it is unclear whether TLR5 plays a significant role during infection [39]. In uninfected cells, in the absence of NLR/TLR activation, NF-KB is held in an inactive state by binding to its inhibitor $I_{\kappa} B$ [28]. When NLRs/TLRs are stimulated, the signal is transmitted (via the adaptors Receptor-interacting serine/threonine kinase 2 (RIPK2) or Myeloid differentiation primary response 88/TIR-domain-containing adapter-inducing interferon- $\beta$ (MyD88/TRIF) respectively) to the IKB kinase (IKK) complex composed of NF-KB essential modulator (NEMO), IKK $\alpha$, and IKK $\beta$. The activated IKK complex phosphorylates $I \kappa B \alpha$, which is ubiquitylated and degraded by the proteasome, freeing NF- $\kappa B$ to be translocated to the nucleus and perform its transcription factor function (Figure 1) $[28,29]$. NLR/TLR signaling also activates MAPK pathways via the TGF $\beta$-activated kinase 1 (TAK1) which contributes to the induction of pro-inflammatory genes by downstream transcription factors such as Activator protein-1 (AP-1; Figure 1) [40,41].

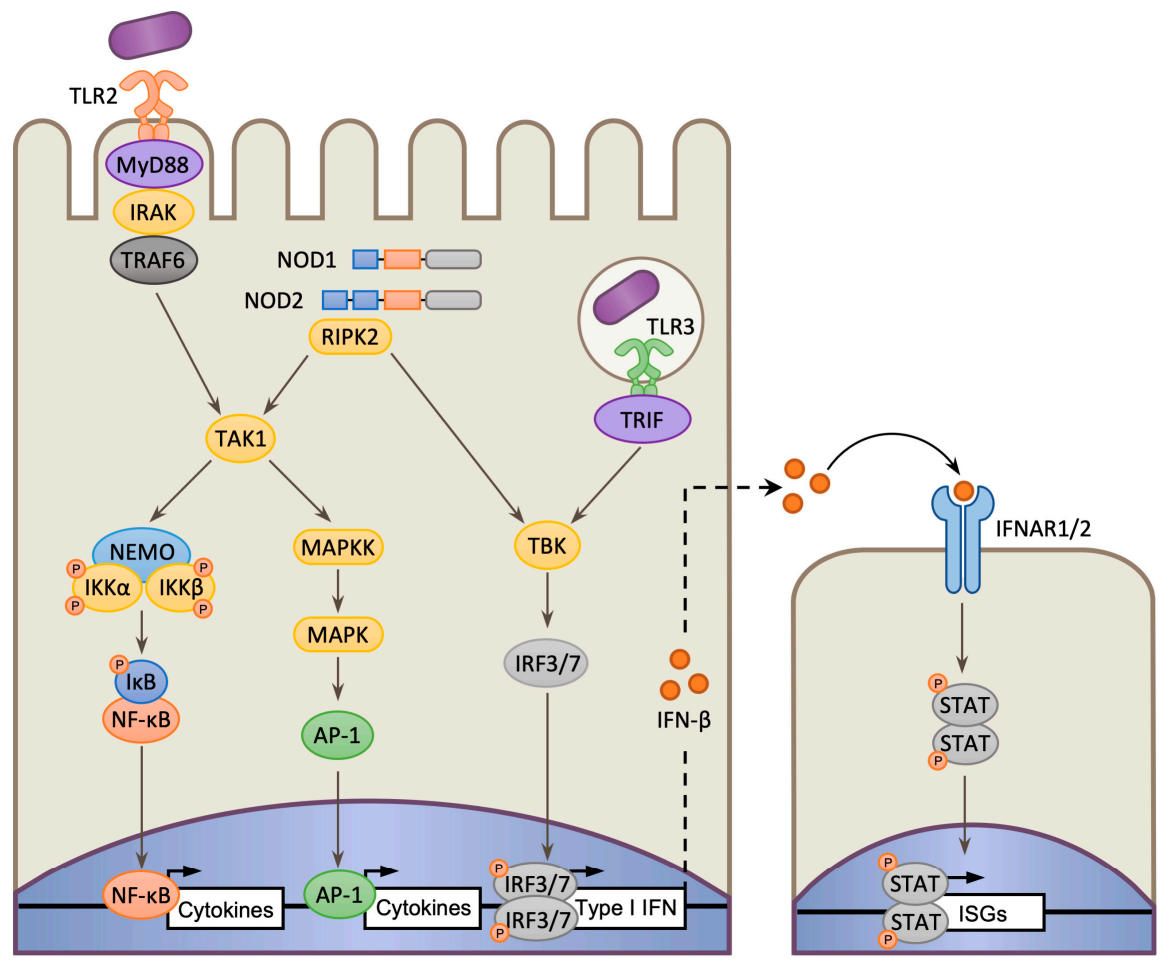

Figure 1. Toll-like receptors (TLR) and nucleotide-binding domain and leucine-rich repeat (NLR) receptor signaling in response to L. monocytogenes $(\mathrm{Lm})$. TLR2 recognizes lipoproteins (LP) or lipoteichoic acids (LTA) and transmits via a signal transduction pathway including Myeloid differentiation primary response 88 (MyD88), IL-1R-associated kinase (IRAK) proteins and TNF receptor-associated factor 6 (TRAF6). NOD1 and NOD2 recognize diaminopimelic acid (DAP) and muramyl dipeptide (MDP) respectively, resulting in RIPK2 recruitment and activation. These converge on TGF $\beta$-activated kinase 1 (TAK1) which triggers two diverging pathways: activation of the IKB kinase (IKK) complex resulting in NF- $\mathrm{KB}$ activation and; Mitogen-activated protein kinase (MAPK) cascade which culminates in the activation of the transcription factor Activator protein-1 (AP-1). IKK $\beta$ then phosphorylates the I $\mathrm{B}$ which is ubiquitinated and degraded by the proteasome. NF- $\mathrm{kB}$ is translocated to the nucleus where it initiates transcription of pro-inflammatory cytokines and other genes involved in immune processes. NOD1/2 and TLR3 (via TIR-domain-containing adapter-inducing interferon- $\beta$ (TRIF)) can also stimulate type-I interferon production via TANK-binding protein 1 (TBK) and interferon regulatory transcription factors 3/7 (IRF3/7). 
In vivo studies in mice have demonstrated that NLR/TLR-mediated NF- $\mathrm{kB}$ responses are protective and important for restricting bacterial infection. However, because NLRs and TLRs are not ubiquitously or uniformly expressed across different cell types and tissues, the role of certain receptors in mediating inflammation can vary depending on the site of $L m$ infection. For instance, despite high expression of most NLRs and TLRs in phagocytic cells, the loss of one type of receptor in vivo cannot be functionally complemented by the presence of another [40,42-45]. During systemic Lm infection, NOD1 and TLR2 play a pronounced role in inflammatory responses, as mice which lack either receptor exhibit diminished inflammation, higher bacterial burden in the spleen and liver, and higher mortality [45-48]. On the contrary, during intragastric infection, NOD2 is suggested to have a dominant protective role $[47,48]$. However, the role of TLRs during intestinal infections in vivo is less clear as they are weakly expressed in the small intestine [49]. One study has shown that mice lacking the MyD88 adaptor poorly activate antimicrobial responses in the intestine, however, such a result could be explained by the role of this adaptor downstream of other receptors (i.e., IL-1 receptors (IL-1Rs)) [50].

Along with the initiation of broad transcriptional changes, receptor signaling also triggers histone modifications, which typically correlate with transcriptional activity, and promote pro-inflammatory responses [51,52]. In human umbilical vein endothelial cells (HUVECs), infection causes a specific increase in the levels of histone $\mathrm{H} 4-\mathrm{Lys}^{8}$ acetylation (H4K8-ac), histone $\mathrm{H} 3 \mathrm{Ser}^{10}$ phosphorylation, and $\mathrm{Lys}^{14}$ acetylation (H3K14-ac) at the promoters of pro-inflammatory genes, such as IL8 [53]. These histone modifications are triggered by NOD1-induced MAP kinase signaling in response to cytosolic Lm (Figure 2) [54]; and temporally correlate with the recruitment of the acetyltransferase CREB-binding protein (CBP), and the loss of Histone deacetylase 1 (HDAC1), suggesting these enzymes may be responsible for regulating the histone acetylation. As IL8 is a key cytokine and chemoattractant for neutrophils, which are essential for the clearance of $L m$ in vivo, this process likely has a role in promoting a protective immune response [55]. Interestingly, histone modifications are only targeted to a subset of inflammatory genes, as the IFNG locus is not modified, despite being induced by infection. Therefore, the induction of histone modifications at specific genes likely fine tunes the host transcriptional response and imposes an extra layer of regulation.

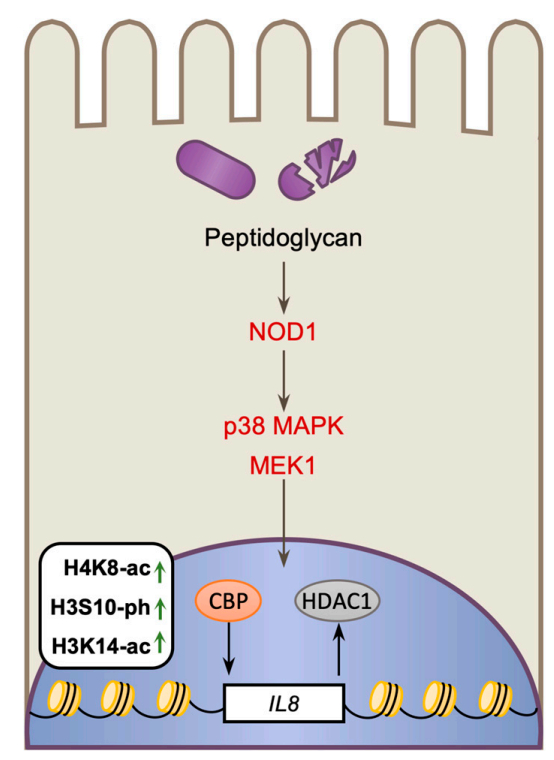

Figure 2. Infection-induced alterations to histone modifications in the host. Lm infection induces transcription of the IL8 cytokine gene following the detection of cytoplasmic peptidoglycan by NOD1. Induction of IL8 expression correlates with an increase in the histone modifications: H4K8-ac, H3S10-ph and H3K14-ac; which is dependent on p38 and MAPK/ERK kinase 1 (MEK1) signaling. The appearance of these histone modifications correlates with the recruitment of the acetyltransferase CREB-binding protein (CBP) and the loss of the histone deacetylase Histone deacetylase 1 (HDAC1) from the promoter of IL8. 


\subsection{Interferon-Regulated Transcriptional Profile}

Interferon signaling is another major characteristic of $L m$-induced transcriptional changes. Interferons (IFNs) play important roles in immunity and are grouped into type-I (IFN- $\beta$ ), type-II $($ IFN- $\gamma$ ), and type-III (IFN- $\lambda$ ) IFNs $[56,57]$. IFNs have primarily been studied for their antiviral role, however it is now appreciated that they also function in anti-bacterial responses; in fact IFN- $\beta$, $\gamma$, and $\lambda$ have all been found to be released, and to activate ISGs in response to Lm infection [57]. Interestingly, some IFNs can produce variable immune outcomes depending on the context of infection, which in certain situations can enhance $L m$ infection [34].

In nonphagocytic cells, $L m$-induced IFN- $\beta$ signaling results in the activation of ISGs, such as the ubiquitin-like protein ISG15 which promotes cytokine secretion and restriction of bacterial intracellular growth [58]. Similar effects are also observed in vivo, for instance during gastrointestinal infection of mice, where IFN- $\beta$ signaling helps mitigate the establishment of systemic infection by triggering rapid induction of protective cytokines [59,60]. Administering exogenous IFN- $\beta$ can also elicit a protective host response during systemic infection, however this effect is limited to the first few hours of infection [61]. IFN- $\beta$ is induced following direct sensing of bacteria-derived products. Both TLR2/3 and NOD2 have been shown to contribute to the induction of IFN- $\beta$ in macrophages (Figure 1) [21,62]; however more notable are the roles of additional families of cytosolic PRRs (Figure 3) [20,22]. At the center of these responses is the host receptor Stimulator of interferon genes (STING), which induces IFN- $\beta$ expression via its interactions with TANK-binding protein 1 (TBK1) and interferon regulatory transcription factor 3 (IRF3) [63]. Subsequently, IFN- $\beta$-induced activation of the Janus kinase/Signal transducers and activators of transcription (JAK-STAT) signaling pathway results in the induction of ISGs. STING acts as a central hub for multiple sensory pathways. In murine cells STING recognizes bacterial c-di-AMP which is secreted into the host via bacterial multidrug efflux pumps (MDRs), such as MdrM and MdrT (Figure 3A) [64,65]. By contrast, in human cells, STING is primarily activated in response to bacterial-derived cytosolic DNA and RNA, which are recognized by cGAMP synthase (cGAS) and Retinoic acid-inducible protein I receptor (RIG-I), respectively [66,67]. When cGAS binds DNA, it becomes activated and produces the cyclic nucleotide cGAMP, which subsequently activates STING (Figure 3C) [66]; whereas RIG-I forms a complex with Mitochondrial antiviral signaling protein (MAVS) and triggers IFN- $\beta$ production through interactions with STING (Figure 3C) or via TBK1-induced IRF3 phosphorylation (Figure 3E) [67-69]. Despite the protective role of IFN- $\beta$ in the gut $[59,61]$, it has been shown to promote $L m$ pathogenesis during systemic infection by disrupting the generation of beneficial immune responses $[34,60,70,71]$. Interestingly, $L m$ possesses mechanisms that seemly function to actively elicit an IFN- $\beta$ response, suggesting that, in some instances, its induction may represent a strategy used to enhance the susceptibility of the host to infection, a process discussed further on in this review (Section 3.1).

IFN- $\gamma$ has been shown to be protective during many bacterial infections $[72,73]$. In the early stages of systemic $L m$ infection, cytokines IL-12 and IL-18 (secreted by infected macrophages) induce IFN- $\gamma$ secretion from natural killer (NK)- and $\gamma \delta$ T-cells [72,74-76]. IFN- $\gamma$-stimulated macrophages then induce ISGs, such as guanylate-binding proteins (GBPs), which promote direct killing of Lm, and initiate robust, protective antimicrobial responses [77-79]. In mice, IFN- $\lambda$ expression is also observed in $L m$ infected placentas, suggesting it may have a role in regulating the fetoplacental barrier during infection [80]. 


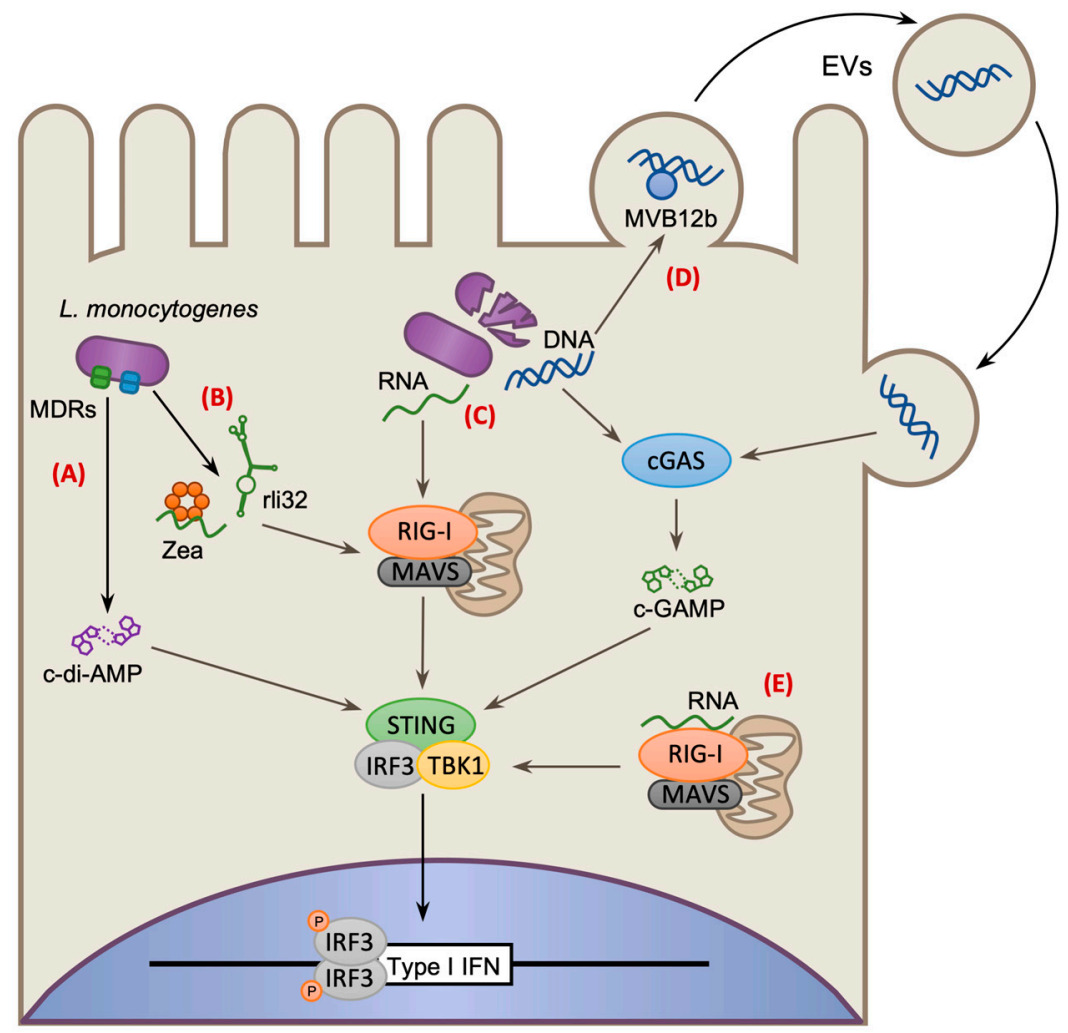

Figure 3. Mechanisms of type-I interferon (IFN) induction by L. monocytogenes via Stimulator of interferon genes (STING). Activated STING forms a platform for the recruitment of the interferon regulatory transcription factor 3 (IRF3) transcription factor and TANK-binding protein 1 (TBK1) kinase. IRF3 is phosphorylated by TBK1 and forms an active homodimer that translocates to the nucleus and initiates type-I IFN gene expression. (A) $L m$ secretes c-di-AMP through multidrug efflux pumps (MDRs). c-di-AMP is then recognized by STING, which activates and initiates type-I IFN expression via IRF3. (B) $L m$ secretes specific RNA molecules into the host to elicit type-I IFN. $L m$ can secrete sncRNAs such as rli32 and prophage-derived RNAs via a bacterial RNA-binding protein (RBP) called Zea. These result in activation of the cytosolic RNA receptor Retinoic acid-inducible protein I receptor (RIG-I), which can trigger type-I IFN expression via STING-dependent and independent mechanisms. (C) Lm releases DNA and RNA passively by bacterial autolysis or through active secretion. Cytoplasmic DNA is detected by the sensor cGAMP synthase (cGAS) which produces the cyclic nucleotide cGAMP to activate STING, whereas RNA is detected by RIG-I which signals to STING via Mitochondrial antiviral signaling protein (MAVS). (D) Lm DNA is packaged into host-derived extracellular vesicles (EVs) these can then fuse to neighboring cells to stimulate type-I IFN via cGAS and STING. (E) RIG-I can also signal independently of STING via TBK1 leading to the activation of IRF3.

\section{Modification of Host Transcriptional Responses by L. monocytogenes}

Induction of pro-inflammatory and antimicrobial genes are essential for the host to combat and clear bacterial infections. Therefore, it is unsurprising that bacterial pathogens have evolved diverse strategies to inhibit or subvert the expression of antimicrobial factors.

\subsection{Exploitation of Antagonist Crosstalk in Interferon Signaling}

In contrast to the response seen in the gastrointestinal tract, multiple studies have demonstrated that IFN- $\beta$ can make the host more susceptible to systemic infection $[34,70,71]$. Notably, Lm possesses two mechanisms that can enhance its virulence by activating RIG-I-dependent IFN- $\beta$ signaling $[67,81,82]$. In the first mechanism, $L m$ secretes small noncoding RNAs (sncRNAs) into the host cytosol, activating RIG-I, and resulting in IFN- $\beta$ signaling which promotes $L m$ intracellular survival. One sncRNA, called rli32, displays particularly potent stimulation of IFN- $\beta$ signaling, and its deletion greatly attenuates 
the growth and survival of $L m$ in macrophages (Figure 3B) [82]. The second mechanism requires the action of a bacterial RNA-binding protein (RBP) called Zea, which shuttles phage-derived RNA into the host cytosol to activate RIG-I, resulting in significant induction of IFN- $\beta$ in epithelial cells (Figure 3B). However, during intravenous infection, Zea appears to reduce $L m$ virulence as $\Delta z e a$ strains display increased bacteria burden in the organs of infected mice, further illustrating that the temporal expression of IFN- $\beta$ is tightly regulated in both pro- and anti-bacterial responses [81].

IFN- $\beta$ is thought to sensitize the host to $L m$ infection by disrupting various immune processes. For instance, IFN- $\beta$ has been shown to trigger T-cells apoptosis, resulting in a dampened immune response [83]; and suppress expression of CXC chemokines, causing reduced neutrophil infiltration and bacterial clearance [84]. This can also impact subsequent infections, as STING-dependent activation of IFN- $\beta$, during an initial $L m$ challenge, blocks the priming and expansion of CD8+ T-cells, rendering mice more sensitive to re-infection [85]. IFN- $\beta$ also downregulates the expression the IFN- $\gamma$ receptor in macrophages, thereby suppressing the protective properties of IFN- $\gamma$ signaling $[71,86]$. This IFN type-specific antagonistic crosstalk is exploited by many bacterial pathogens in order to promote their infection $[34,71,87,88]$.

Interestingly, $L m$ not only influences the transcription in infected cells, but also targets surrounding bystander cells. In infected macrophages, bacterial DNA was shown to be packaged and secreted in extracellular vehicles (EVs) by the host protein MVB12b, which is activated upon infection in a STING and TBK-1 dependent manner (Figure 3D). These EVs fuse with neighboring uninfected cells and stimulate cGAS-STING-dependent production of IFN- $\beta$, which promotes T-cell apoptosis in vivo [33]. However, although IFN- $\beta$ can promote $L m$ pathogenesis, continuous and unrestricted induction of IFN- $\beta$ can also negatively impact infection. Due to overexpression of the MDR MdrT, the $L m$ strain LO28 hyper-induces IFN- $\beta$ production and, as a result, is attenuated during systemic infection [65]. This shows that the host-sensitizing effects of IFN- $\beta$ has site and temporal specificity during infection, and must be tightly regulated by $L m$ in order to fine tune host responses [65]. Other bacteria such as Mycobacterium leprae, Mycobacterium tuberculosis, and Salmonella enterica Typhimurium have also been described to exploit the induction of IFN- $\beta$ responses, implying this may be a common strategy employed during bacterial infection $[34,87,88]$.

\subsection{Virulence Factor-Induced Activation of Host Transcription}

Host-mediated induction of classical pro-inflammatory responses usually occurs following the detection of MAMPs, which are often bacterial structural components or metabolites. However, a number of $L m$ virulence factors can also serve as activators of transcriptional processes in addition to their primary pathogenic function. As such, virulence factor-induced responses could either be an additional means of immune detection, which may serve to distinguish pathogenic from non-pathogenic organisms, or yet another host process that is exploited to suit the pathogen's needs.

The pore forming toxin Listeriolysin (LLO), encoded by hly, primarily serves to promote bacterial escape from vacuoles; however it can also induce rapid NF- $\mathrm{KB}$ activation in endothelial cells, resulting in specific upregulation of adhesins and certain cytokines [89], which is also seen following treatment with purified recombinant LLO toxin. In contrast, non-hemolytic or $\Delta h l y$ strains activate NF- $\kappa B$ to a slower and lesser degree, suggesting that early NF- $\mathrm{B}$ responses in endothelial cells may, in large part, be dependent on LLO and not solely on MAMPs, as is the case in immune cells such as macrophages [90]. Further molecular studies have shown that LLO pores induce the activation of IKK $\beta$, leading to NF- $\kappa \mathrm{B}$ activation. Interestingly, this required Interleukin-1 receptor, type I (IL-1R1) but was independent of IL-1 cytokines, MyD88, and IL-1R-associated kinase (IRAK), which are essential in canonical IL-1R1 signaling [91]. Similarly, in Caco-2 intestinal epithelial cells, LLO-induced calcium influx triggers NF- $\mathrm{B}$ activation resulting in the induction of IL-6. The same study also demonstrated that LLO activity preserves $I L-6$ expression, resulting in persistent IL-6 secretion [92].

NF- $\kappa B$ activation in intestinal epithelial cells can also be influenced by Listeria adhesion protein (LAP), a multifunctional surface protein that promotes adhesion and translocation through the 
epithelium. LAP binds to surface expressed Hsp60, which activates pro-inflammatory NF- $\mathrm{kB}$ signaling and the Myosin light-chain kinase MLCK; thereby enhancing epithelium permeability, promoting bacterial intestinal translocation, and increasing systemic dissemination [93].

Internalin B (InlB), binds to its host receptor c-MET, and behaves as a functional mimic of the native agonist Hepatocyte growth factor (HGF). As well as mediating host cell invasion, InlB also stimulates multiple host signaling pathways, either while anchored to the bacterium, or as a free soluble cofactor [94,95]. Upon InlB binding, c-MET activates Phosphoinositide 3-kinase (PI3-K) which triggers AKT, JUN N-terminal kinase (JNK), and MAPK signaling cascades [94-99]. Many of these pathways communicate with host cell transcriptional machinery, thereby inducing a $L m$-specific host program. In murine J774 macrophages, InlB has been shown to activate NF- $\mathrm{KB}$ via PI3-K and AKT, likely via IKK $\alpha[97,100,101]$. Interestingly, the binding of InlB to c-MET occurs in a different region than HGF and generates more robust signaling cascade kinetics, raising the question whether the transcriptional responses induced by InlB and HGF are the same $[98,99,102]$.

\subsection{Direct Targeting of Host Transcription Factor Function}

Because NF- $\mathrm{kB}$ plays a central role in immune and inflammatory responses, it and its surrounding regulatory factors are common targets of bacterial virulence factors [103-105]. Lm is no exception and utilizes the virulence factor Internalin C (InlC) to disrupt NF-kB activation in macrophages [30]. InlC expression and secretion is induced upon the entry of $L m$ into the host cytosol, where it binds to the IKK $\alpha$ subunit of the IKK complex. This interaction suppresses phosphorylation and subsequent degradation of $I \kappa B \alpha$, thereby preventing the nuclear translocation of NF- $k B$, and blocking its transcriptional processes (Figure $4 \mathrm{~A}$ ). InlC therefore reduces the induction of pro-inflammatory cytokines during infection, and in mice, suppresses the recruitment of polymorphonuclear leukocytes to the site of infection [30]. In epithelial cells, IKK $\alpha$ has also been described to phosphorylate histone H3 to promote gene expression [106,107]. Therefore, InlC may also impact gene expression by affecting IKK $\alpha$-induced histone phosphorylation, however further study is necessary. Recently, it has been shown that InlC is monoubiquitylated in host cells, which causes it to interact with the alarmin S100A9. Interestingly, this process promotes reactive oxygen species production by neutrophils and enhances host defense to infection, suggesting that InlC ubiquitylation might act as a host defense mechanism, that permits the induction of protective inflammatory signaling following the detection of bacterial virulence factors [108].

\subsection{Indirect Targeting of Host Transcription Factor by Disruption of PTMs}

PTMs such as phosphorylation, acetylation, ubiquitylation, and SUMOylation have the capacity to modify the activity of proteins, enabling rapid functional changes without the need for new transcription. As a result, disrupting PTM machineries is a common strategy used by pathogens to interfere with host processes [109]. For instance, LLO has been shown to trigger the dephosphorylation and inactivation of MAPK proteins p38, and Extracellular signal-regulated kinase 1/2 (ERK1/2) during $\mathrm{Lm}$ infection of trophoblast giant cells (Figure 4B). This inactivates c-Jun, a component of the AP-1 transcription factor, and promotes cell death through the downregulation of Heme oxygenase (HO)-1, a promoter of cell survival [110]. 
A

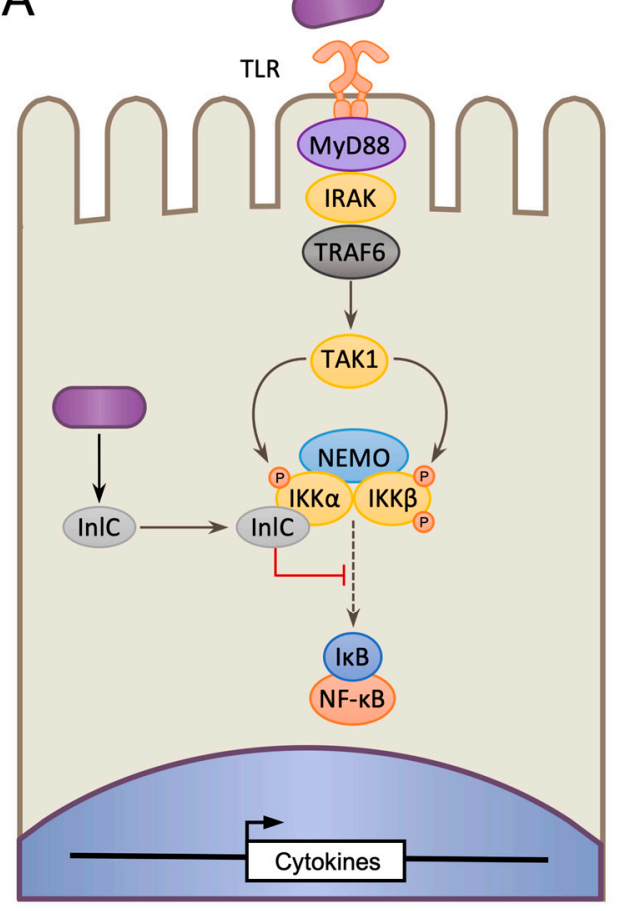

B

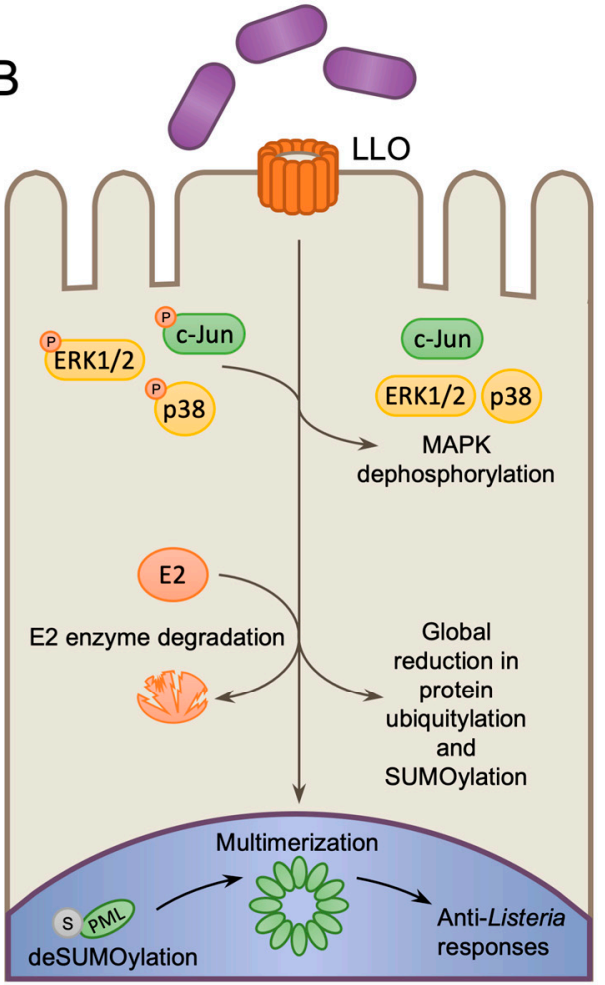

Figure 4. Altering host gene expression by disrupting transcriptional regulators. (A) The Lm effector internalin $\mathrm{C}$ ( InlC) is produced and secreted when bacteria enter the host cytosol. InlC binds to IKK $\alpha$ and blocks IкB phosphorylation and degradation thereby inhibiting NF- $\mathrm{B}$ B nuclear translocation and the transcription of NF-kB-regulated gene. (B) Listeriolysin (LLO) blocks the phosphorylation of multiple enzymes in the Mitogen-activated protein kinase (MAPK) pathway thereby inhibiting the activation of downstream transcription factors such as c-Jun. LLO also induces proteolysis of ubiquitin and Small ubiquitin-like modifier (SUMO) E2-conjugating enzymes, causing a global decrease in ubiquitylated and SUMOlyated proteins, many of which, are transcription factors. The transcription regulator promyelocytic leukemia protein (PML) also undergoes deSUMOlyation in response to LLO, causing it multimerize and induce anti-Listeria responses.

In non-phagocytic cells $\mathrm{Lm}$ also targets host ubiquitylation and SUMOylation. During infection, LLO triggers proteasomal-independent degradation of multiple ubiquitin E2 conjugating enzymes, and the sole Small ubiquitin-like modifier (SUMO) E2 enzyme UBC9, resulting in global loss of protein ubiquitylation and SUMOylation (Figure 4B) [111-114]. Ubiquitylation and SUMOylation regulate many proteins that control gene expression and inflammatory signaling $[115,116]$. Indeed, many of the proteins that are differentially modified during infection are transcription factors [111,113]. Therefore, by targeting these modifications, $L m$ could potentially have wide-reaching influence over multiple transcriptional and nuclear processes within the host, however, the full impact of targeting these proteins is yet to be determined [111]. The promyelocytic leukemia protein (PML), which regulates nuclear body formation, is one such target of LLO-induced deSUMOylation, and has been shown to play a role in restricting $L m$ growth. PML appears to act as a sensor of pore formation, as deSUMOylation causes PML multimerization, which in turn triggers the expression of antibacterial cytokines, and transcription factors that help the cell combat infection (Figure 4B) [117].

\subsection{Modulation via Host Derived microRNAs}

MicroRNAs (miRNAs) are a class of small non-coding RNA, which post-transcriptionally repress gene expression by targeting complementary mRNAs for degradation by the RNA-induced silencing complex (RISC) [118]. Since their discovery, miRNAs have been established to regulate a number of 
physiological processes, including the regulation of specific host mRNAs during bacterial infection [118]. During $L m$ infection, many miRNAs are differentially expressed, however it remains to be shown whether these processes result in changes that are beneficial for $L m$ or the host. In macrophages, $L m$ induces the production of miR-155, miR-125a-3p, miR-125a-5p, miR-146a, and miR-149, all of which are implicated in regulating immune-related genes (Figure 5A). Upregulation of these miRNAs occurs independently of LLO but requires MyD88, suggesting that they are induced by MyD88-dependent receptors such as TLRs and IL-1Rs [119]. Similarly, Lm also alters miRNA expression in Caco-2 epithelial cells by inducing the expression of miR-155, and to a lesser extent miR-146b and miR-16 (Figure 5B). These up-regulated miRNAs are predicted to regulate multiple pro-inflammatory cytokines such as IL6 and IL8, and are also up-regulated in response to purified LLO toxin [120]. Two other miRNAs, let-7a1 and miR-145, are in fact suppressed during infection (Figure 5B). let-7a1 has been reported to regulate multiple transcripts of genes involved in the regulation of cell proliferation and metabolism, such as c-Myc [121], whereas miR-145 is predicted to regulate IFN- $\beta$ [120]. By extrapolating their function, it can be hypothesized that infection-induced upregulation of these miRNAs could, in turn, suppress inflammatory responses by inducing the degradation of targeted cytokine mRNAs.
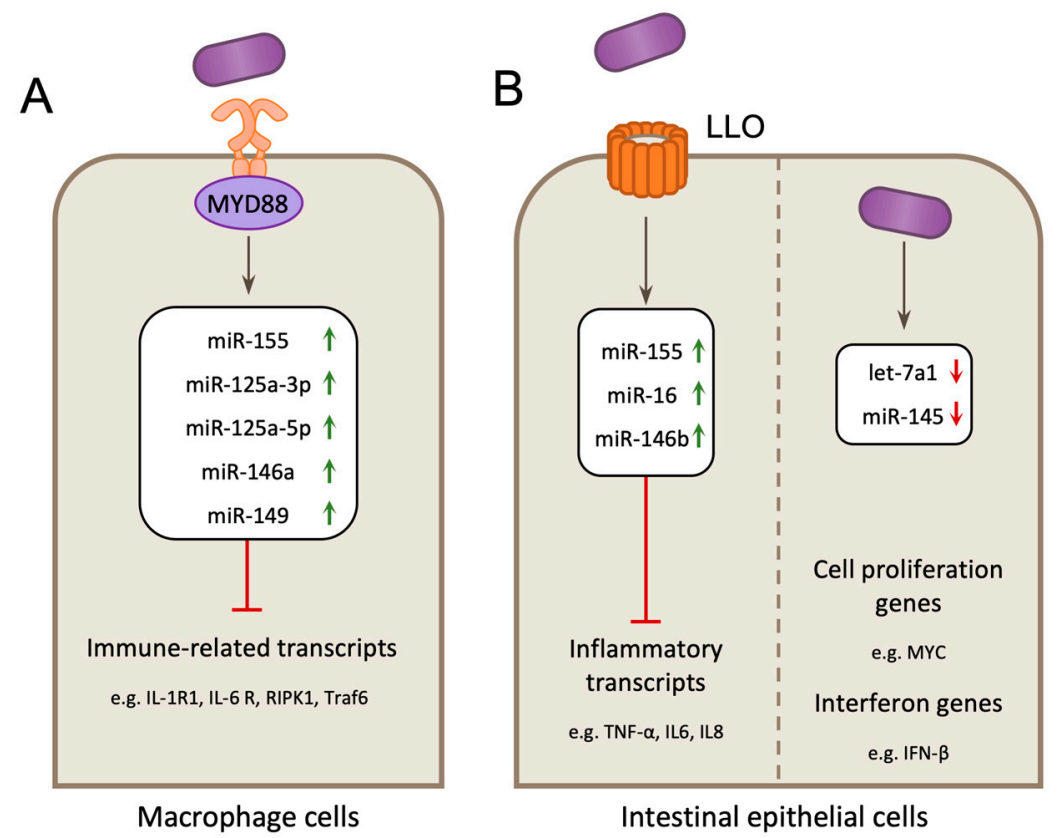

Figure 5. L. monocytogenes infection-induced changes in host microRNA (miRNA) expression. (A) In macrophage cells infection with L. monocytogenes causes significant upregulation of miRNAs miR-155, miR-146a, miR-125a-3p/5p and miR-149 in mouse bone marrow-derived macrophages. Upregulation was independent of Listeriolysin O (LLO) and required the host receptor adaptor MyD88 suggesting this occurs via MyD88-dependent receptor signaling (e.g., Toll-like receptors (TLRs) and Interleukin-1 receptor, type I (IL-1R)). These miRNAs target genes involved in the innate immune response. (B) In intestinal epithelial cells (Caco-2 cells) miR-155, miR-146b and miR-16 are induced upon infection, or treatment with purified LLO. miRNAs let-7a1 and miR-145 are down-regulated by infection in Caco- 2 cells. let-7a1 is predicted to regulate expression of genes involved cell proliferation and metabolism such as Myc and miR-145 is predicted to target IFN- $\beta$.

\section{Targeting Host-Epigenetic Mechanisms}

\subsection{LLO-Induced Changes to Histone Modifications}

LLO functions in many aspects of Lm infection and is often described as a "swiss army knife" [122]. It is unsurprising then that LLO can also alter host histone modifications and was in fact the first $L m$ virulence factor shown to do so [123]. In epithelial cells, infection or treatment with recombinant 
LLO toxin, triggers a global loss histone $\mathrm{H} 4$ acetylation (H4-ac) and histone H3S10 phosphorylation (H3S10-ph), both of which have been linked to active gene transcription (Figure 6A). In fact, LLO activity alters the expression of 146 host genes (47 repressed and 99 induced). Gene repression is correlated with reduced levels of $\mathrm{H} 3 \mathrm{~S} 10$-ph and $\mathrm{H} 4$-ac at gene promoters, while those that are induced have increased levels. Suppressed genes included the chemokine CXCL2 and the phosphatase DUSP4, both of which have roles in the inflammatory response. Therefore, this mechanism may serve to dampen the immune response to Lm infection. Mechanistically, it has been determined that H3S10 dephosphorylation is dependent on LLO pore-induced potassium ion efflux [32] and can be triggered by other pore-forming toxins including perfringolysin O (PFO) and pneumolysin (PLY). Recently, both LLO and PLY induced dephosphorylation of H3S10-ph was shown to be dependent on the host Protein phosphatase 1 (PP1), which is itself activated by dephosphorylation in response to infection [124].

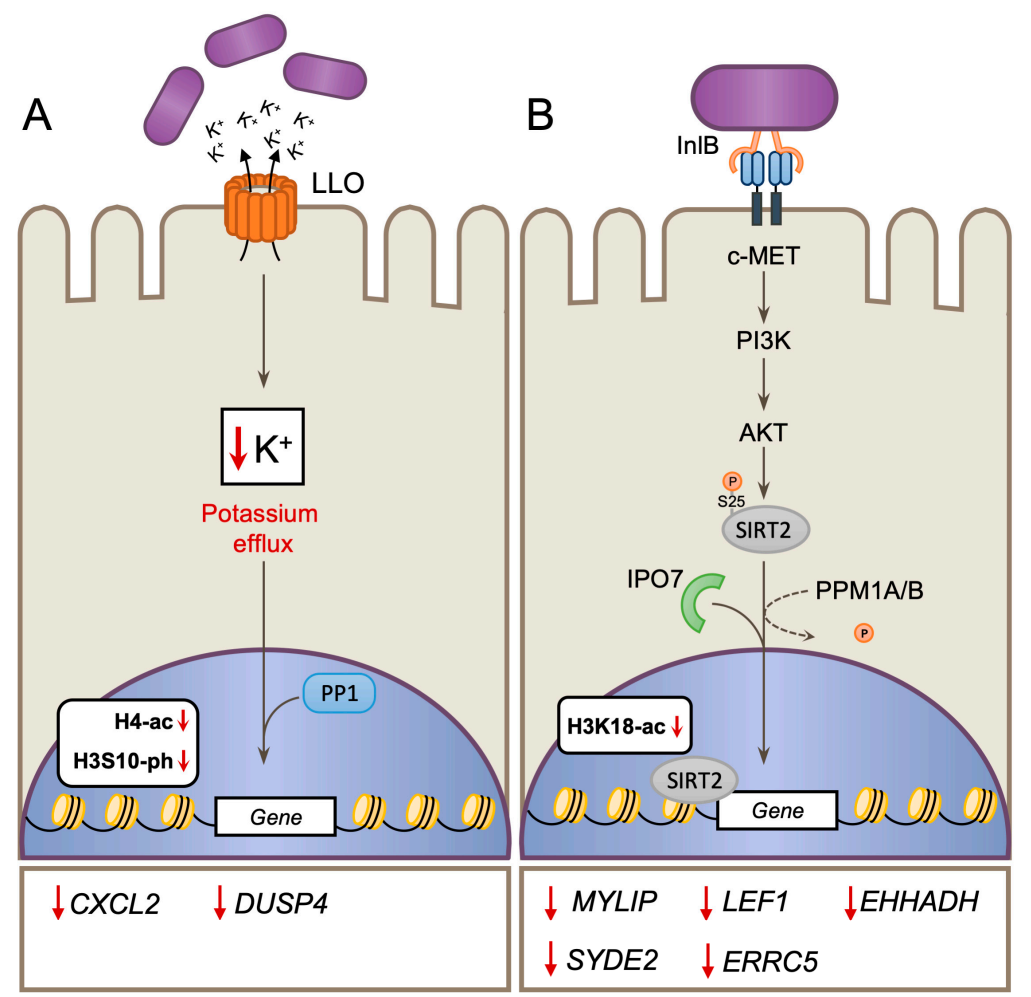

Histone modification-regulated genes

Figure 6. Infection-induced alterations to histone modifications in the host. (A) Lm infection or purified Listeriolysin O (LLO) induces global reduction in H4-ac and H3S10-ph which correlates with the down regulation of CXCL2 and DUSP4 genes. H3S10 dephosphorylation is dependent on LLO pore-induced potassium ion $\left(\mathrm{K}^{+}\right)$efflux [32] and requires the activity of the host Protein phosphatase 1 (PP1) [122]. (B) Internalin B (InlB) induced c-MET/Phosphoinositide 3-kinase (PI3K)/AKT signaling triggers redistribution of Sirtuin 2 (SIRT2) to host chromatin, deacetylation of H3K18 and gene repression. The host Importin 7 (IPO7) and SIRT2 dephosphorylation serine 25 (S25) by Protein phosphatases 1A/1B (PPM1A/PPM1B) are required for H3K18 deacetylation to occur. SIRT2 targets specific genes (e.g., MYLIP) which show concurrent enrichment of SIRT2, loss off H3K18 acetylation (H3K18-ac) and repressed gene expression.

\subsection{InlB-Dependent H3K18 Deacetylation by SIRT2}

By virtue of its signaling capabilities via c-MET, the internalin InlB is able to trigger specific deacetylation of histone $\mathrm{H} 3$ at lysine 18 (H3K18) through hijacking of the NAD+ dependent deacetylase enzyme Sirtuin 2 (SIRT2). Activation of the c-MET/Phosphoinositide 3-kinase (PI3K)/AKT signaling axis during infection, causes SIRT2, which usually maintains a cytoplasmic localization, to be redistributed 
to host chromatin where it deacetylates H3K18 [125] (Figure 6B). This process is dependent on host Importin 7 (IPO7) [126]; and Protein phosphatases 1A/1B (PPM1A/PPM1B), which dephosphorylate SIRT2 at serine 25 to permit its association with chromatin. [127]. SIRT2 activity during infection causes widespread transcriptional reprogramming of the host, resulting in the repression of 272 genes [125]. Examining repressed genes by chromatin immunoprecipitation (CHIP) PCR, showed that SIRT2 becomes enriched at gene promoters and correlates with H3K18 deacetylation. Conversely, genes whose expression remains unaltered by infection showed no change in SIRT2 or H3K18-ac, suggesting that SIRT2-dependent H3 deacetylation is gene loci specific. Deacetylation of H3K18 appears to play an important role during infection, as inhibition or knockdown of either SIRT2 or PPM1A/PPM1B suppresses bacterial intracellular survival without affecting bacterial invasion [125,127]. Similarly, SIRT2 deficiency also restricts $L m$ survival during infection in vivo. Certain SIRT2-repressed genes, such as LEF1 and CXCL12, have roles in regulating immune responses. Therefore, the modulation of SIRT2 by Lm may serve as a general strategy to block or down-regulate the induction of immune and antimicrobial responses at both cell-intrinsic and systemic levels.

\subsection{Chromatin-Targeting Bacterial Factors}

Virulence factors such as LLO and InlB enable $L m$ to alter the transcriptional output of cells by subverting or hijacking native host signaling processes. However, $L m$ also produces factors that directly target the nucleus and chromatin structure. $L m$ has specialized effectors termed nucleomodulins, which specifically enter the host cell nucleus and target nuclear/chromatin factors that regulate gene expression. The first such factor to be described in $L m$ was LntA, a secreted protein that modulates the activity of the host heterochromatinization factor BAHD1 (Figure 7). In vertebrates, BAHD1 interacts with transcription factors, such as $\mathrm{SP1}$, at $\mathrm{CpG}$-rich promotors, where it acts as a platform for the recruitment of chromatin silencing factors such as heterochromatin protein 1 (HP1 $\alpha, \beta$, and $\gamma)$, MBD1, KMT1E, HDAC5, and CHD1. Once recruited, these factors cause heterochromatin formation and gene silencing of cell proliferation and survival genes as well as ISGs during Lm infection [128-130].

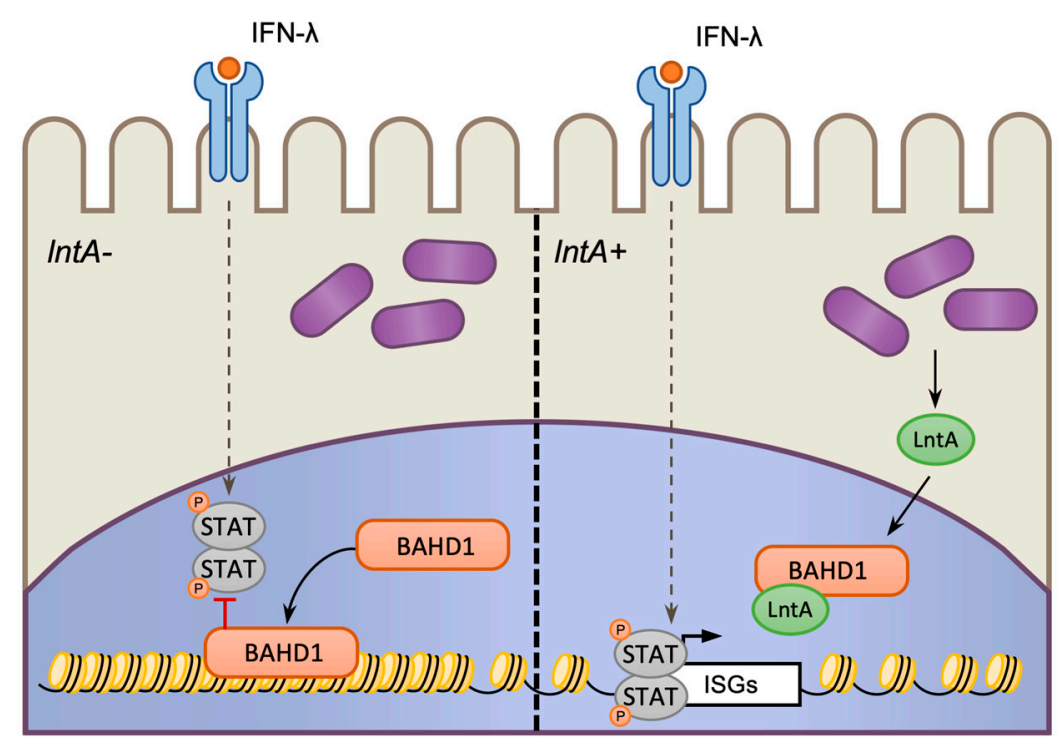

Figure 7. Regulation of host gene expression via LntA-targeting of host BAHD1 protein. Lm infection induces the production of IFN- $\lambda$ which stimulates the expression of IFN-stimulated genes (ISGs). During infection with $L m$ which lack the nucleomodulin LntA the repressor complex protein BAHD1 is activated, binds to ISGs and blocks their expression by Signal transducers and activators of transcription (STAT) factors (left). When LntA is expressed it is secreted into the cytosol of infected cells and binds to BAHD1, preventing it from interacting with chromatin and blocking ISG expression (right). 
Although LntA is regulated by PrfA and SigB, the timing and the location of its expression in vivo remains poorly understood $[129,131]$. When LntA is expressed, it localizes to the nucleus and binds to BAHD1, preventing it from repressing the expression of ISGs, and resulting in IFN- $\lambda$-dependent gene expression. However, when LntA is not expressed, BAHDI is able to bind to promoters and block transcription of ISGs downstream of IFN- $\lambda$ signaling, which is maintained during infection (Figure 7). Interestingly, deletion or constitutive expression of LntA reduces bacterial virulence resulting in lower bacterial burdens in infected mice. Thus, LntA appears to have an important role in fine-tuning IFN- $\lambda$-dependent transcriptional responses at specific points during the infection process $[129,130]$.

\section{Conclusions and Perspectives}

During infection, mammalian cells undergo significant transcriptional reprogramming to bring about the necessary inflammatory and antimicrobial responses to combat the pathogen. These processes require the concerted action of receptors, signaling pathways, transcriptional factors, and epigenetic mechanisms to engage a robust and protective transcriptional response. Concurrently, bacterial pathogens utilize diverse mechanisms to manipulate host transcriptional pathways at all levels, in order to create a more favorable niche for survival and replication. These dynamics are well represented during $L m$ infection, which as discussed above, triggers widespread global transcriptional changes in its host. In the broadest sense, transcriptional responses either act in favor of the host (triggered by conserved bacterial MAMPS), or the pathogen (triggered by specialized bacterial virulence factors).

However, in some cases this distinction is not always clear, highlighting an interesting dichotomy in host-pathogen interactions whereby the line between host- and pathogen-regulated responses can be hard to distinguish. Despite not being considered virulence factors, $L m$ utilizes both passive and active mechanisms to release molecules such ci-di-AMP or rli32, which are not directly involved in specific pathogenic function but nonetheless impact infection. Likewise, the fact that virulence factors, such as LLO, also induce typically anti-microbial responses raises the same questions. On one hand, such events could be considered as the "detection" of a virulence factor, resulting in activation of an antimicrobial response; whereas on the other, it could function to promote bacterial virulence. For instance, in the case of InlB, AKT-mediated activation of NF- $\mathrm{kB}$ has also been implicated in blocking apoptosis, therefore this mechanism may serve to help promote a pro-survival response in infected cells, thereby promoting the intracellular cycle of the pathogen [101]. Similarly, in non-phagocytic cells, InlB is implicated in activating pro-survival signaling via the ERK1/2 kinases and STAT3 transcription factor. Although a precise transcriptional network of InlB signaling is yet to be determined, treating endothelial cells with recombinant InlB has been demonstrated to block the induction of apoptosis in response to angiotensin II, suggesting that these pathways could function to promote host cell survival during infection, thereby maintaining the intracellular niche of $\operatorname{Lm}$ [132]. In these instances, whether a transcriptional response is deliberately activated as a means of host manipulation can be difficult distinction to make, and is further complicated by the fact that blocking virulence factor activity often perturbs infection and pathogenesis (i.e., invasion or phagosome escape). Another level of complexity is introduced when the presence of other bacterial species, such as the components of the microbiota, are considered. Recent advances in microbiome research have shown that the gut microbiota can influence intestinal homeostasis and immunity by modulating host epitranscriptomic [133] and epigenetic modifications [134-136]. Lm is known to produce bacteriocins that kill other bacteria to promote its own infection, therefore, it may also be able to affect the transcriptional profile of its host by targeting specific members of the host gut microbiome $[137,138]$. Though this requires further study, it could represent yet another mechanism through which Lm influences the transcriptional profile of its host.

Studying the dynamic interface of transcriptional regulation during infection allows us to discover how pathogens exploit their host to promote their own pathogenesis, and sheds light on potential new targets for therapeutics, in both the pathogen and the host. Though still in its early stages of development, the concept of host-directed immunomodulatory therapies is an attractive alternative to 
bacterial targeted treatments such as antibiotics, as resistance to such treatment is, theoretically, more difficult to develop. The study of epigenetics brings further scope and potential to the development of such treatments, whereby they could be designed to be long lasting and cross protective for multiple pathogens $[139,140]$.

In summary, despite the significant progress made in the study of transcriptional responses to infection, current microarray studies do not appropriately illustrate the more nuanced changes that can be regulated by $L m$ virulence factors, and many questions still remain. For instance, how heterogenous are bacterial-induced changes within infected tissue? It is possible that these changes function through precise fine-tuning of specific genes, allowing their effects to be global without having a drastic impact on the transcriptional profile of the host. This could be particularly true of the epigenetic-regulated changes, as these appear to display significant gene loci specificity. For example, this is illustrated by LLO-mediated suppression of CXCL2, which is also induced as part of the NF- $\mathrm{kB}$ transcriptional profile [21]. Furthermore, it remains to be demonstrated how transcriptional changes induced by pathogen virulence factors mechanistically confer an advantage to the pathogen within the host; and in the context of epigenetic mechanisms, how long they may persist, and whether they act on cell intrinsic, local or systemic levels. From these examples, it is clear that the innate immune response to bacterial infection is greatly influenced by transcriptional and epigenetic changes, however these can be highly varied and contextually nuanced. Studying these heterogenous responses will help better our understanding of human pathology during infectious disease.

Author Contributions: Writing—original draft preparation, M.J.G.E.; writing—review and editing, M.J.G.E., P.C., and M.A.H. All authors have read and agreed to the published version of the manuscript.

Funding: M.J.G.E. is supported by a fellowship from the French Government's Investissement d'Avenir program, the Laboratoire d'Excellence "Integrative Biology of Emerging Infectious Diseases" (ANR-10-LABX-62-IBEID). P.C. is funded by the Fondation le Roch les Mousquetaires and the Fondation Balzan. Work in the Chromatin and Infection Group is supported by the Pasteur Institute and the Agence National de la Recherche (ANR-EpiBActIn).

Acknowledgments: We would like to thank Sanika Vaidya and Julia Sanchez-Garrido for critical reading of the manuscript. We apologize to any colleagues whose work was not included in this review.

Conflicts of Interest: The authors declare no conflict of interest.

\section{References}

1. Allis, C.D.; Jenuwein, T. The molecular hallmarks of epigenetic control. Nat. Rev. Genet. 2016, 17, 487-500. [CrossRef]

2. Bannister, A.J.; Kouzarides, T. Regulation of chromatin by histone modifications. Cell Res. 2011, 21, 381-395. [CrossRef]

3. Kouzarides, T. Chromatin Modifications and Their Function. Cell 2007, 128, 693-705. [CrossRef]

4. Suganuma, T.; Workman, J.L. Signals and Combinatorial Functions of Histone Modifications. Annu. Rev. Biochem. 2011, 80, 473-499. [CrossRef] [PubMed]

5. Tropberger, P.; Schneider, R. Scratching the (lateral) surface of chromatin regulation by histone modifications. Nat. Struct. Mol. Biol. 2013, 20, 657-661. [CrossRef] [PubMed]

6. Shogren-Knaak, M.; Ishii, H.; Sun, J.M.; Pazin, M.J.; Davie, J.R.; Peterson, C.L. Histone H4-K16 acetylation controls chromatin structure and protein interactions. Science 2006, 311, 844-847. [CrossRef] [PubMed]

7. Lachner, M.; O'Carroll, D.; Rea, S.; Mechtler, K.; Jenuwein, T. Methylation of histone H3 lysine 9 creates a binding site for HP1 proteins. Nature 2001, 410, 116-120. [CrossRef]

8. Ezhkova, E.; Pasolli, H.A.; Parker, J.S.; Stokes, N.; Su, I.H.; Hannon, G.; Tarakhovsky, A.; Fuchs, E. Ezh2 Orchestrates Gene Expression for the Stepwise Differentiation of Tissue-Specific Stem Cells. Cell 2009, 136, 1122-1135. [CrossRef]

9. Jenuwein, T.; Allis, C.D. Translating the histone code. Science 2001, 293, 1074-1080. [CrossRef]

10. Strahl, B.D.; Allis, C.D. The language of covalent histone modifications. Nature 2000, 403, 41-45. [CrossRef]

11. Vermeulen, M.; Mulder, K.W.; Denissov, S.; Pijnappel, W.W.M.P.; van Schaik, F.M.A.; Varier, R.A.; Baltissen, M.P.A.; Stunnenberg, H.G.; Mann, M.; Timmers, H.T.M. Selective Anchoring of TFIID to Nucleosomes by Trimethylation of Histone H3 Lysine 4. Cell 2007, 131, 58-69. [CrossRef] [PubMed] 
12. Agalioti, T.; Chen, G.; Thanos, D. Deciphering the transcriptional histone acetylation code for a human gene. Cell 2002, 111, 381-392. [CrossRef]

13. Josling, G.A.; Selvarajah, S.A.; Petter, M.; Duffy, M.F. The Role of Bromodomain Proteins in Regulating Gene Expression. Genes 2012, 3, 320-343. [CrossRef] [PubMed]

14. Zeng, L.; Zhang, Q.; Gerona-Navarro, G.; Moshkina, N.; Zhou, M.M. Structural Basis of Site-Specific Histone Recognition by the Bromodomains of Human Coactivators PCAF and CBP/p300. Structure 2008, 16, 643-652. [CrossRef] [PubMed]

15. Umehara, T.; Nakamura, Y.; Jang, M.K.; Nakano, K.; Tanaka, A.; Ozato, K.; Padmanabhan, B.; Yokoyama, S. Structural basis for acetylated histone H4 recognition by the human BRD2 bromodomain. J. Biol. Chem. 2010, 285, 7610-7618. [CrossRef]

16. Bannister, A.J.; Zegerman, P.; Partridge, J.F.; Miska, E.A.; Thomas, J.O.; Allshire, R.C.; Kouzarides, T. Selective recognition of methylated lysine 9 on histone H3 by the HP1 chromo domain. Nature 2001, 410, 120-124. [CrossRef]

17. Machida, S.; Takizawa, Y.; Ishimaru, M.; Sugita, Y.; Sekine, S.; Nakayama, J.I.; Wolf, M.; Kurumizaka, H. Structural Basis of Heterochromatin Formation by Human HP1. Mol. Cell 2018, 69, 385-397.e8. [CrossRef]

18. Baldwin, D.N.; Vanchinathan, V.; Brown, P.O.; Theriot, J.A. A gene-expression program reflecting the innate immune response of cultured intestinal epithelial cells to infection by Listeria monocytogenes. Genome Biol. 2003, 4, R2.

19. Nau, G.J.; Richmond, J.F.L.; Schlesinger, A.; Jennings, E.G.; Lander, E.S.; Young, R.A. Human macrophage activation programs induced by bacterial pathogens. Proc. Natl. Acad. Sci. USA 2002, 99, 1503-1508. [CrossRef]

20. McCaffrey, R.L.; Fawcett, P.; O’Riordan, M.; Lee, K.D.; Havell, E.A.; Brown, P.O.; Portnoy, D.A. A specific gene expression program triggered by Gram-positive bacteria in the cytosol. Proc. Natl. Acad. Sci. USA 2004, 101, 11386-11391. [CrossRef]

21. Leber, J.H.; Crimmins, G.T.; Raghavan, S.; Meyer-Morse, N.P.; Cox, J.S.; Portnoy, D.A. Distinct TLR- and NLR-Mediated Transcriptional Responses to an Intracellular Pathogen. PLoS Pathog. 2008, 4, e6. [CrossRef] [PubMed]

22. Lecuit, M.; Sonnenburg, J.L.; Cossart, P.; Gordon, J.I. Functional genomic studies of the intestinal response to a foodborne enteropathogen in a humanized gnotobiotic mouse model. J. Biol. Chem. 2007, 282, 15065-15072. [CrossRef] [PubMed]

23. Pitt, J.M.; Blankley, S.; Potempa, K.; Graham, C.M.; Moreira-Teixeira, L.; McNab, F.W.; Howes, A.; Stavropoulos, E.; Pascual, V.; Banchereau, J.; et al. Analysis of Transcriptional Signatures in Response to Listeria monocytogenes Infection Reveals Temporal Changes That Result from Type I Interferon Signaling. PLoS ONE 2016, 11, e0150251. [CrossRef] [PubMed]

24. Radoshevich, L.; Cossart, P. Listeria monocytogenes: Towards a complete picture of its physiology and pathogenesis. Nat. Rev. Microbiol. 2018, 16, 32-46. [CrossRef]

25. Pizarro-Cerdá, J.; Kühbacher, A.; Cossart, P. Entry of listeria monocytogenes in mammalian epithelial cells: An updated view. Cold Spring Harb. Perspect. Med. 2012, 2. [CrossRef] [PubMed]

26. Liu, T.; Zhang, L.; Joo, D.; Sun, S.C. NF-кB signaling in inflammation. Signal. Transduct. Target. Ther. 2017, 2, 1-9. [CrossRef] [PubMed]

27. Eldridge, M.J.G.; Shenoy, A.R. Antimicrobial inflammasomes: Unified signalling against diverse bacterial pathogens. Curr. Opin. Microbiol. 2015, 23, 32-41. [CrossRef]

28. Napetschnig, J.; Wu, H. Molecular Basis of NF-кB Signaling. Annu. Rev. Biophys. 2013, 42, $443-468$. [CrossRef]

29. Newton, K.; Dixit, V.M. Signaling in innate immunity and inflammation. Cold Spring Harb. Perspect. Biol. 2012, 4, 3. [CrossRef]

30. Gouin, E.; Adib-Conquy, M.; Balestrino, D.; Nahori, M.A.; Villiers, V.; Colland, F.; Dramsi, S.; Dussurget, O.; Cossart, P. The Listeria monocytogenes InlC protein interferes with innate immune responses by targeting the IkB kinase subunit IKK $\alpha$. Proc. Natl. Acad. Sci. USA 2010, 107, 17333-17338. [CrossRef]

31. Budayeva, H.G.; Cristea, I.M. Human Sirtuin 2 Localization, Transient Interactions, and Impact on the Proteome Point to Its Role in Intracellular Trafficking. Mol. Cell. Proteom. 2016, 15, 3107-3125. [CrossRef] [PubMed] 
32. Hamon, M.A.; Cossart, P. K+ Efflux Is Required for Histone H3 Dephosphorylation by Listeria monocytogenes Listeriolysin $\mathrm{O}$ and Other Pore-Forming Toxins. Infect. Immun. 2011, 79, 2839-2846. [CrossRef] [PubMed]

33. Nandakumar, R.; Tschismarov, R.; Meissner, F.; Prabakaran, T.; Krissanaprasit, A.; Farahani, E.; Zhang, B.C.; Assil, S.; Martin, A.; Bertrams, W.; et al. Intracellular bacteria engage a STING-TBK1-MVB12b pathway to enable paracrine cGAS-STING signalling. Nat. Microbiol. 2019, 4, 701-713. [CrossRef] [PubMed]

34. Rayamajhi, M.; Humann, J.; Kearney, S.; Hill, K.K.; Lenz, L.L. Antagonistic crosstalk between type I and II interferons and increased host susceptibility to bacterial infections. Virulence 2010, 1, 418-422. [CrossRef]

35. Lebreton, A.; Stavru, F.; Cossart, P. Organelle targeting during bacterial infection: Insights from Listeria. Trends Cell Biol. 2015, 25, 330-338. [CrossRef]

36. Travassos, L.H.; Girardin, S.E.; Philpott, D.J.; Blanot, D.; Nahori, M.A.; Werts, C.; Boneca, I.G. Toll-like receptor 2-dependent bacterial sensing does not occur via peptidoglycan recognition. EMBO Rep. 2004, 5, 1000-1006. [CrossRef]

37. Regan, T.; Nally, K.; Carmody, R.; Houston, A.; Shanahan, F.; MacSharry, J.; Brint, E. Identification of TLR10 as a Key Mediator of the Inflammatory Response to Listeria monocytogenes in Intestinal Epithelial Cells and Macrophages. J. Immunol. 2013, 191, 6084-6092. [CrossRef]

38. Hayashi, F.; Smith, K.D.; Ozinsky, A.; Hawn, T.R.; Yi, E.C.; Goodlett, D.R.; Eng, J.K.; Akira, S.; Underhill, D.M.; Aderem, A. The innate immune response to bacterial flagellin is mediated by Toll-like receptor 5. Nature 2001, 410, 1099-1103. [CrossRef]

39. Xie, M.; Ding, C.; Guo, L.; Chen, G.; Zeng, H.; Liu, Q. Evaluation of Caco-2 cells response to Listeria monocytogenes virulence factors by RT-PCR. Microb. Pathog. 2018, 120, 79-84. [CrossRef]

40. Park, J.-H.; Kim, Y.-G.; McDonald, C.; Kanneganti, T.-D.; Hasegawa, M.; Body-Malapel, M.; Inohara, N.; Núñez, G. RICK/RIP2 Mediates Innate Immune Responses Induced through Nod1 and Nod2 but Not TLRs. J. Immunol. 2007, 178, 2380-2386. [CrossRef]

41. Stavru, F.; Archambaud, C.; Cossart, P. Cell biology and immunology of Listeria monocytogenes infections: Novel insights. Immunol. Rev. 2011, 240, 160-184. [CrossRef]

42. Kim, Y.G.; Park, J.H.; Shaw, M.H.; Franchi, L.; Inohara, N.; Núñez, G. The Cytosolic Sensors Nod1 and Nod2 Are Critical for Bacterial Recognition and Host Defense after Exposure to Toll-like Receptor Ligands. Immunity 2008, 28, 246-257. [CrossRef] [PubMed]

43. Torres, D.; Barrier, M.; Bihl, F.; Quesniaux, V.J.F.; Maillet, I.; Akira, S.; Ryffel, B.; Erard, F. Toll-Like Receptor 2 Is Required for Optimal Control of Listeria monocytogenes Infection. Infect. Immun. 2004, 72, 2131-2139. [CrossRef] [PubMed]

44. Machata, S.; Tchatalbachev, S.; Mohamed, W.; Jänsch, L.; Hain, T.; Chakraborty, T. Lipoproteins of Listeria monocytogenes Are Critical for Virulence and TLR2-Mediated Immune Activation. J. Immunol. 2008, 181, 2028-2035. [CrossRef]

45. Edelson, B.T.; Unanue, E.R. MyD88-Dependent but Toll-Like Receptor 2-Independent Innate Immunity to Listeria: No Role for Either in Macrophage Listericidal Activity. J. Immunol. 2002, 169, 3869-3875. [CrossRef] [PubMed]

46. Seki, E.; Tsutsui, H.; Tsuji, N.M.; Hayashi, N.; Adachi, K.; Nakano, H.; Futatsugi-Yumikura, S.; Takeuchi, O.; Hoshino, K.; Akira, S.; et al. Critical Roles of Myeloid Differentiation Factor 88-Dependent Proinflammatory Cytokine Release in Early Phase Clearance of Listeria monocytogenes in Mice. J. Immunol. 2002, 169, 3863-3868. [CrossRef] [PubMed]

47. Kobayashi, K.S.; Chamaillard, M.; Ogura, Y.; Henegariu, O.; Inohara, N.; Nuñez, G.; Flavell, R.A. Nod2-dependent regulation of innate and adaptive immunity in the intestinal tract. Science 2005, 307, 731-734. [CrossRef]

48. Mosa, A.; Trumstedt, C.; Eriksson, E.; Soehnlein, O.; Heuts, F.; Janik, K.; Klos, A.; Dittrich-Breiholz, O.; Kracht, M.; Hidmark, Å; et al. Nonhematopoietic cells control the outcome of infection with Listeria monocytogenes in a nucleotide oligomerization domain 1-dependent manner. Infect. Immun. 2009, 77, 2908-2918. [CrossRef]

49. Price, A.E.; Shamardani, K.; Lugo, K.A.; Deguine, J.; Roberts, A.W.; Lee, B.L.; Barton, G.M. A Map of Toll-like Receptor Expression in the Intestinal Epithelium Reveals Distinct Spatial, Cell Type-Specific, and Temporal Patterns. Immunity 2018, 49, 560-575.e6. [CrossRef] 
50. Brandl, K.; Plitas, G.; Schnabl, B.; DeMatteo, R.P.; Pamer, E.G. MyD88-mediated signals induce the bactericidal lectin RegIII $\gamma$ and protect mice against intestinal Listeria monocytogenes infection. J. Exp. Med. 2007, 204, 1891-1900. [CrossRef]

51. Lawrence, M.; Daujat, S.; Schneider, R. Lateral Thinking: How Histone Modifications Regulate Gene Expression. Trends Genet. 2016, 32, 42-56. [CrossRef] [PubMed]

52. Bierne, H.; Hamon, M.; Cossart, P. Epigenetics and bacterial infections. Cold Spring Harb. Perspect. Med. 2012, 2. [CrossRef] [PubMed]

53. Schmeck, B.; Beermann, W.; van Laak, V.; Zahlten, J.; Opitz, B.; Witzenrath, M.; Hocke, A.C.; Chakraborty, T.; Kracht, M.; Rosseau, S.; et al. Intracellular bacteria differentially regulated endothelial cytokine release by MAPK-dependent histone modification. J. Immunol. 2005, 175, 2843-2850. [CrossRef] [PubMed]

54. Opitz, B.; Püschel, A.; Beermann, W.; Hocke, A.C.; Förster, S.; Schmeck, B.; van Laak, V.; Chakraborty, T.; Suttorp, N.; Hippenstiel, S. Listeria monocytogenes Activated p38 MAPK and Induced IL-8 Secretion in a Nucleotide-Binding Oligomerization Domain 1-Dependent Manner in Endothelial Cells. J. Immunol. 2006, 176, 484-490. [CrossRef]

55. Witter, A.R.; Okunnu, B.M.; Berg, R.E. The Essential Role of Neutrophils during Infection with the Intracellular Bacterial Pathogen Listeria monocytogenes. J. Immunol. 2016, 197, 1557-1565. [CrossRef]

56. Platanias, L.C. Mechanisms of type-I- and type-II-interferon-mediated signalling. Nat. Rev. Immunol. 2005, 5, 375-386. [CrossRef]

57. Dussurget, O.; Bierne, H.; Cossart, P. The bacterial pathogen Listeria monocytogenes and the interferon family: Type I, type II and type III interferons. Front. Cell. Infect. Microbiol. 2014, 4. [CrossRef]

58. Radoshevich, L.; Impens, F.; Ribet, D.; Quereda, J.J.; Tham, T.N.; Nahori, M.A.; Bierne, H.; Dussurget, O.; Pizarro-Cerdá, J.; Knobeloch, K.P.; et al. ISG15 counteracts Listeria monocytogenes infection. Elife 2015, 4. [CrossRef]

59. Kernbauer, E.; Maier, V.; Rauch, I.; Müller, M.; Decker, T. Route of Infection Determines the Impact of Type I Interferons on Innate Immunity to Listeria monocytogenes. PLoS ONE 2013, 8, e65007. [CrossRef]

60. Pitts, M.G.; Myers-Morales, T.; D'Orazio, S.E.F. Type I IFN Does Not Promote Susceptibility to Foodborne Listeria monocytogenes. J. Immunol. 2016, 196, 3109-3116. [CrossRef]

61. Pontiroli, F.; Dussurget, O.; Zanoni, I.; Urbano, M.; Beretta, O.; Granucci, F.; Ricciardi-Castagnoli, P.; Cossart, P.; Foti, M. The Timing of IFN $\beta$ Production Affects Early Innate Responses to Listeria monocytogenes and Determines the Overall Outcome of Lethal Infection. PLoS ONE 2012, 7, e43455. [CrossRef] [PubMed]

62. Aubry, C.; Corr, S.C.; Wienerroither, S.; Goulard, C.; Jones, R.; Jamieson, A.M.; Decker, T.; O'Neill, L.A.J.; Dussurget, O.; Cossart, P. Both TLR2 and TRIF Contribute to Interferon- $\beta$ Production during Listeria Infection. PLoS ONE 2012, 7, e33299. [CrossRef] [PubMed]

63. Tanaka, Y.; Chen, Z.J. STING specifies IRF3 phosphorylation by TBK1 in the cytosolic DNA signaling pathway. Sci. Signal. 2012, 5, ra20. [CrossRef] [PubMed]

64. Woodward, J.J.; Lavarone, A.T.; Portnoy, D.A. C-di-AMP secreted by intracellular Listeria monocytogenes activates a host type I interferon response. Science 2010, 328, 1703-1705. [CrossRef]

65. Schwartz, K.T.; Carleton, J.D.; Quillin, S.J.; Rollins, S.D.; Portnoy, D.A.; Leber, J.H. Hyperinduction of host beta interferon by a Listeria monocytogenes strain naturally overexpressing the multidrug efflux pump MdrT. Infect. Immun. 2012, 80, 1537-1545. [CrossRef] [PubMed]

66. Hansen, K.; Prabakaran, T.; Laustsen, A.; Jørgensen, S.E.; Rahbæk, S.H.; Jensen, S.B.; Nielsen, R.; Leber, J.H.; Decker, T.; Horan, K.A.; et al. Listeria monocytogenes induces IFN $\beta$ expression through an IFI16-, cGASand STING-dependent pathway. EMBO J. 2014, 33, 1654-1666. [CrossRef]

67. Abdullah, Z.; Schlee, M.; Roth, S.; Mraheil, M.A.; Barchet, W.; Böttcher, J.; Hain, T.; Geiger, S.; Hayakawa, Y.; Fritz, J.H.; et al. RIG-I detects infection with live Listeria by sensing secreted bacterial nucleic acids. EMBO J. 2012, 31, 4153-4164. [CrossRef]

68. Hagmann, C.A.; Herzner, A.M.; Abdullah, Z.; Zillinger, T.; Jakobs, C.; Schuberth, C.; Coch, C.; Higgins, P.G.; Wisplinghoff, H.; Barchet, W.; et al. RIG-I Detects Triphosphorylated RNA of Listeria monocytogenes during Infection in Non-Immune Cells. PLoS ONE 2013, 8, e62872. [CrossRef]

69. Zevini, A.; Olagnier, D.; Hiscott, J. Crosstalk between Cytoplasmic RIG-I and STING Sensing Pathways. Trends Immunol. 2017, 38, 194-205. [CrossRef] 
70. O'Connell, R.M.; Saha, S.K.; Vaidya, S.A.; Bruhn, K.W.; Miranda, G.A.; Zarnegar, B.; Perry, A.K.; Nguyen, B.O.; Lane, T.F.; Taniguchi, T.; et al. Type I interferon production enhances susceptibility to Listeria monocytogenes infection. J. Exp. Med. 2004, 200, 437-445. [CrossRef]

71. Rayamajhi, M.; Humann, J.; Penheiter, K.; Andreasen, K.; Lenz, L.L. Induction of IFN- $\alpha \beta$ enables Listeria monocytogenes to suppress macrophage activation by IFN- $\gamma$. J. Exp. Med. 2010, 207, 327-337. [CrossRef] [PubMed]

72. Huang, S.; Hendriks, W.; Althage, A.; Hemmi, S.; Bluethmann, H.; Kamijo, R.; Vilček, J.; Zinkernagel, R.M.; Aguet, M. Immune response in mice that lack the interferon- $\gamma$ receptor. Science 1993, 259, 1742-1745. [CrossRef] [PubMed]

73. Harty, J.T.; Bevant, M.J. Specific immunity to listeria monocytogenes in the absence of IFN $\gamma$. Immunity 1995, 3, 109-117. [CrossRef]

74. Hiromatsu, K.; Yoshikai, Y.; Matsuzaki, G.; Ohga, S.; Muramori, K.; Matsumoto, K.; Bluestone, J.A.; Nomoto, K. A protective role of $\gamma / \delta$ T cells in primary inaction with Listeria monocytogenes in mice. J. Exp. Med. 1992, 175, 49-56. [CrossRef]

75. Tripp, C.S.; Wolf, S.F.; Unanue, E.R. Interleukin 12 and tumor necrosis factor $\alpha$ are costimulators of interferon $\gamma$ production by natural killer cells in severe combined immunodeficiency mice with listeriosis, and interleukin 10 is a physiologic antagonist. Proc. Natl. Acad. Sci. USA 1993, 90, 3725-3729. [CrossRef] [PubMed]

76. Andersson, A.; Dai, W.J.; Di Santo, J.P.; Brombacher, F. Early IFN-gamma production and innate immunity during Listeria monocytogenes infection in the absence of NK cells. J. Immunol. 1998, 161, 5600-5606. [PubMed]

77. Kim, B.H.; Shenoy, A.R.; Kumar, P.; Das, R.; Tiwari, S.; MacMicking, J.D. A family of IFN- $\gamma$-inducible 65-kD GTPases protects against bacterial infection. Science 2011, 332, 717-721. [CrossRef]

78. Shenoy, A.R.; Wellington, D.A.; Kumar, P.; Kassa, H.; Booth, C.J.; Cresswell, P.; MacMicking, J.D. GBP5 Promotes NLRP3 inflammasome assembly and immunity in mammals. Science 2012, 336, 481-485. [CrossRef]

79. Kernbauer, E.; Maier, V.; Stoiber, D.; Strobl, B.; Schneckenleithner, C.; Sexl, V.; Reichart, U.; Reizis, B.; Kalinke, U.; Jamieson, A.; et al. Conditional Stat1 Ablation Reveals the Importance of Interferon Signaling for Immunity to Listeria monocytogenes Infection. PLoS Pathog. 2012, 8, e1002763. [CrossRef]

80. Bierne, H.; Travier, L.; Mahlakõiv, T.; Tailleux, L.; Subtil, A.; Lebreton, A.; Paliwal, A.; Gicquel, B.; Staeheli, P.; Lecuit, M.; et al. Activation of Type III Interferon Genes by Pathogenic Bacteria in Infected Epithelial Cells and Mouse Placenta. PLoS ONE 2012, 7, e39080. [CrossRef]

81. Pagliuso, A.; Tham, T.N.; Allemand, E.; Robertin, S.; Dupuy, B.; Bertrand, Q.; Bécavin, C.; Koutero, M.; Najburg, V.; Nahori, M.A.; et al. An RNA-Binding Protein Secreted by a Bacterial Pathogen Modulates RIG-I Signaling. Cell Host Microbe 2019, 26, 823-835.e11. [CrossRef]

82. Frantz, R.; Teubner, L.; Schultze, T.; La Pietra, L.; Müller, C.; Gwozdzinski, K.; Pillich, H.; Hain, T.; Weber-Gerlach, M.; Panagiotidis, G.D.; et al. The secRNome of Listeria monocytogenes harbors small noncoding rnas that are potent inducers of beta interferon. MBio 2019, 10. [CrossRef]

83. Carrero, J.A.; Unanue, E.R. Lymphocyte apoptosis as an immune subversion strategy of microbial pathogens. Trends Immunol. 2006, 27, 497-503. [CrossRef]

84. Brzoza-Lewis, K.L.; Jason Hoth, J.; Hiltbold, E.M. Type I interferon signaling regulates the composition of inflammatory infiltrates upon infection with Listeria monocytogenes. Cell. Immunol. 2012, 273, 41-51. [CrossRef]

85. Archer, K.A.; Durack, J.; Portnoy, D.A. STING-Dependent Type I IFN Production Inhibits Cell-Mediated Immunity to Listeria monocytogenes. PLoS Pathog. 2014, 10, e1003861. [CrossRef]

86. Kearney, S.J.; Delgado, C.; Eshleman, E.M.; Hill, K.K.; O'Connor, B.P.; Lenz, L.L. Type I IFNs Downregulate Myeloid Cell IFN- $\gamma$ Receptor by Inducing Recruitment of an Early Growth Response 3/NGFI-A Binding Protein 1 Complex That Silences ifngr1 Transcription. J. Immunol. 2013, 191, 3384-3392. [CrossRef]

87. Teles, R.M.B.; Graeber, T.G.; Krutzik, S.R.; Montoya, D.; Schenk, M.; Lee, D.J.; Komisopoulou, E.; Kelly-Scumpia, K.; Chun, R.; Iyer, S.S.; et al. Type I interferon suppresses type II interferon-triggered human anti-mycobacterial responses. Science 2013, 339, 1448-1453. [CrossRef]

88. Crisler, W.J.; Lenz, L.L. Crosstalk between type I and II interferons in regulation of myeloid cell responses during bacterial infection. Curr. Opin. Immunol. 2018, 54, 35-41. [CrossRef] 
89. Makó, V.; Czúcz, J.; Weiszhár, Z.; Herczenik, E.; Matkó, J.; Prohászka, Z.; Cervenak, L. Proinflammatory activation pattern of human umbilical vein endothelial cells induced by IL-1 $\beta$, TNF- $\alpha$, and LPS. Cytom. Part $A$ 2010, 77A, 962-970. [CrossRef]

90. Kayal, S.; Lilienbaum, A.; Poyart, C.; Memet, S.; Israel, A.; Berche, P. Listeriolysin O-dependent activation of endothelial cells during infection with Listeria monocytogenes: Activation of NF-kappaB and upregulation of adhesion molecules and chemokines. Mol. Microbiol. 1999, 31, 1709-1722. [CrossRef]

91. Kayal, S.; Lilienbaum, A.; Join-Lambert, O.; Li, X.; Israël, A.; Berche, P. Listeriolysin O secreted by Listeria monocytogenes induces NF-kB signalling by activating the IkB kinase complex. Mol. Microbiol. 2002, 44, 1407-1419. [CrossRef]

92. Tsuchiya, K.; Kawamura, I.; Takahashi, A.; Nomura, T.; Kohda, C.; Mitsuyama, M. Listeriolysin O-induced membrane permeation mediates persistent interleukin-6 production in Caco-2 cells during Listeria monocytogenes infection in vitro. Infect. Immun. 2005, 73, 3869-3877. [CrossRef]

93. Drolia, R.; Tenguria, S.; Durkes, A.C.; Turner, J.R.; Bhunia, A.K. Listeria Adhesion Protein Induces Intestinal Epithelial Barrier Dysfunction for Bacterial Translocation. Cell Host Microbe 2018, 23, 470-484.e7. [CrossRef]

94. Shen, Y.; Naujokas, M.; Park, M.; Ireton, K. InIB-dependent internalization of Listeria is mediated by the Met receptor tyrosine kinase. Cell 2000, 103, 501-510. [CrossRef]

95. Ireton, K.; Payrastre, B.; Cossart, P. The Listeria monocytogenes protein InlB is an agonist of mammalian phosphoinositide 3-kinase. J. Biol. Chem. 1999, 274, 17025-17032. [CrossRef]

96. Li, N.; Xiang, G.S.; Dokainish, H.; Ireton, K.; Elferink, L.A. The Listeria protein internalin B mimics hepatocyte growth factor-induced receptor trafficking. Traffic 2005, 6, 459-473. [CrossRef]

97. Mansell, A.; Khelef, N.; Cossart, P.; O’Neill, L.A.J. Internalin B Activates Nuclear Factor- $\mathrm{k}$ B via Ras, Phosphoinositide 3-Kinase, and Akt. J. Biol. Chem. 2001, 276, 43597-43603. [CrossRef]

98. Niemann, H.H.; Jäger, V.; Butler, P.J.G.; van den Heuvel, J.; Schmidt, S.; Ferraris, D.; Gherardi, E.; Heinz, D.W. Structure of the Human Receptor Tyrosine Kinase Met in Complex with the Listeria Invasion Protein InlB. Cell 2007, 130, 235-246. [CrossRef]

99. Copp, J.; Marino, M.; Banerjee, M.; Ghosh, P.; Van der Geer, P. Multiple regions of internalin B contribute to its ability to turn on the Ras-mitogen-activated protein kinase pathway. J. Biol. Chem. 2003, 278, 7783-7789. [CrossRef]

100. Mansell, A.; Braun, L.; Cossart, P.; O'neill, L.A.J. A novel function of InlB from Listeria monocytogenes: Activation of NF-kappaB in J774 macrophages. Cell. Microbiol. 2000, 2, 127-136. [CrossRef]

101. Ozes, O.N.; Mayo, L.D.; Gustin, J.A.; Pfeffer, S.R.; Pfeffer, L.M.; Donner, D.B. NF-кB activation by tumour necrosis factor requires tie Akt serine- threonine kinase. Nature 1999, 401, 82-85. [CrossRef]

102. Hamon, M.; Bierne, H.; Cossart, P. Listeria monocytogenes: A multifaceted model. Nat. Rev. Microbiol. 2006, 4, 423-434. [CrossRef]

103. Johannessen, M.; Askarian, F.; Sangvik, M.; Sollid, J.E. Bacterial interference with canonical NFkB signalling. Microbiology (U. K.) 2013, 159, 2001-2013. [CrossRef]

104. Le Negrate, G. Subversion of innate immune responses by bacterial hindrance of NF- $\mathrm{B}$ pathway. Cell. Microbiol. 2012, 14, 155-167. [CrossRef]

105. Rahman, M.M.; McFadden, G. Modulation of NF-kB signalling by microbial pathogens. Nat. Rev. Microbiol. 2011, 9, 291-306. [CrossRef]

106. Yamamoto, Y.; Verma, U.N.; Prajapati, S.; Kwak, Y.-T.; Gaynor, R.B. Histone H3 phosphorylation by IKK- $\alpha$ is critical for cytokine-induced gene expression. Nature 2003, 423, 655-659. [CrossRef]

107. Anest, V.; Hanson, J.L.; Cogswell, P.C.; Steinbrecher, K.A.; Strahl, B.D.; Baldwin, A.S. A nucleosomal function for ikb kinase- $\alpha$ in nf-kb-dependent gene expression. Nature 2003, 423, 659-663. [CrossRef]

108. Gouin, E.; Balestrino, D.; Rasid, O.; Nahori, M.A.; Villiers, V.; Impens, F.; Volant, S.; Vogl, T.; Jacob, Y.; Dussurget, $\mathrm{O}$; et al. Ubiquitination of listeria virulence factor inlc contributes to the host response to infection. MBio 2019, 10, e02778-19. [CrossRef]

109. Ribet, D.; Cossart, P. Post-translational modifications in host cells during bacterial infection. FEBS Lett. 2010, 584, 2748-2758. [CrossRef]

110. Hashino, M.; Tachibana, M.; Nishida, T.; Hara, H.; Tsuchiya, K.; Mitsuyama, M.; Watanabe, K.; Shimizu, T.; Watarai, M. Inactivation of the MAPK signaling pathway by Listeria monocytogenes infection promotes trophoblast giant cell death. Front. Microbiol. 2015, 6, 1145. [CrossRef] 
111. Impens, F.; Radoshevich, L.; Cossart, P.; Ribet, D. Mapping of SUMO sites and analysis of SUMOylation changes induced by external stimuli. Proc. Natl. Acad. Sci. USA 2014, 111, 12432-12437. [CrossRef]

112. Ribet, D.; Hamon, M.; Gouin, E.; Nahori, M.A.; Impens, F.; Neyret-Kahn, H.; Gevaert, K.; Vandekerckhove, J.; Dejean, A.; Cossart, P. Listeria monocytogenes impairs SUMOylation for efficient infection. Nature 2010, 464, 1192-1195. [CrossRef]

113. Malet, J.K.; Impens, F.; Carvalho, F.; Hamon, M.A.; Cossart, P.; Ribet, D. Rapid remodeling of the host epithelial cell proteome by the listeriolysin O (LLO) pore-forming toxin. Mol. Cell. Proteomics 2018, 17, 1627-1636. [CrossRef]

114. Eldridge, M.J.G.; Sanchez-Garrido, J.; Hoben, G.F.; Goddard, P.J.; Shenoy, A.R. The Atypical Ubiquitin E2 Conjugase UBE2L3 Is an Indirect Caspase-1 Target and Controls IL-1 $\beta$ Secretion by Inflammasomes. Cell Rep. 2017, 18, 1285-1297. [CrossRef]

115. Hendriks, I.A.; Vertegaal, A.C.O. A comprehensive compilation of SUMO proteomics. Nat. Rev. Mol. Cell Biol. 2016, 17, 581-595. [CrossRef]

116. Wilkinson, K.A.; Henley, J.M. Mechanisms, regulation and consequences of protein SUMOylation. Biochem. J. 2010, 428, 133-145. [CrossRef]

117. Ribet, D.; Lallemand-Breitenbach, V.; Ferhi, O.; Nahori, M.A.; Varet, H.; De Thé, H.; Cossart, P. Promyelocytic leukemia protein (PML) controls listeria monocytogenes infection. MBio 2017, 8. [CrossRef]

118. Zhou, X.; Li, X.; Wu, M. miRNAs reshape immunity and inflammatory responses in bacterial infection. Signal. Transduct. Target. Ther. 2018, 3, 1-13. [CrossRef]

119. Schnitger, A.K.D.; Machova, A.; Mueller, R.U.; Androulidaki, A.; Schermer, B.; Pasparakis, M.; Krönke, M.; Papadopoulou, N. Listeria monocytogenes infection in macrophages induces vacuolar-dependent host miRNA response. PLoS ONE 2011, 6, e27435. [CrossRef]

120. Izar, B.; Mannala, G.K.; Mraheil, M.A.; Chakraborty, T.; Hain, T. MicroRNA response to listeria monocytogenes infection in epithelial cells. Int. J. Mol. Sci. 2012, 13, 1173-1185. [CrossRef]

121. Guo, M.; Zhao, X.; Yuan, X.; Jiang, J.; Li, P. MiR-let-7a inhibits cell proliferation, migration, and invasion by down-regulating PKM2 in cervical cancer. Oncotarget 2017, 8, 28226-28236. [CrossRef]

122. Hamon, M.A.; Ribet, D.; Stavru, F.; Cossart, P. Listeriolysin O: The Swiss army knife of Listeria. Trends Microbiol. 2012, 20, 360-368. [CrossRef]

123. Hamon, M.A.; Batsché, E.; Régnault, B.; Tham, T.N.; Seveau, S.; Muchardt, C.; Cossart, P. Histone modifications induced by a family of bacterial toxins. Proc. Natl. Acad. Sci. USA 2007, 104, 13467-13472. [CrossRef]

124. Dong, W.; Rasid, O.; Chevalier, C.; Connor, M.; Eldridge, M.J.G.; Hamon, M.A. Streptococcus pneumoniae Infection Promotes Histone H3 Dephosphorylation by Modulating Host PP1 Phosphatase. Cell Rep. 2020, 30, 4016-4026.e4. [CrossRef]

125. Eskandarian, H.A.; Impens, F.; Nahori, M.-A.; Soubigou, G.; Coppée, J.-Y.; Cossart, P.; Hamon, M.A. A Role for SIRT2-Dependent Histone H3K18 Deacetylation in Bacterial Infection. Science 2013, 341, 1238858. [CrossRef]

126. Eldridge, M.J.G.; Pereira, J.M.; Impens, F.; Hamon, M.A. Active nuclear import of the deacetylase Sirtuin-2 is controlled by its C-terminus and importins. Sci. Rep. 2020, 10, 1-12. [CrossRef]

127. Pereira, J.M.; Chevalier, C.; Chaze, T.; Gianetto, Q.; Impens, F.; Matondo, M.; Cossart, P.; Hamon, M.A. Infection Reveals a Modification of SIRT2 Critical for Chromatin Association. Cell Rep. 2018, 23, 1124-1137. [CrossRef]

128. Bierne, H.; Tham, T.N.; Batsche, E.; Dumay, A.; Leguillou, M.; Kernéis-Golsteyn, S.; Regnault, B.; Seeler, J.S.; Muchardt, C.; Feunteun, J.; et al. Human BAHD1 promotes heterochromatic gene silencing. Proc. Natl. Acad. Sci. USA 2009, 106, 13826-13831. [CrossRef]

129. Lebreton, A.; Lakisic, G.; Job, V.; Fritsch, L.; Tham, T.N.; Camejo, A.; Matteï, P.J.; Regnault, B.; Nahori, M.A.; Cabanes, D.; et al. A bacterial protein targets the BAHD1 chromatin complex to stimulate type III interferon response. Science 2011, 331, 1319-1321. [CrossRef]

130. Lebreton, A.; Job, V.; Ragon, M.; Le Monnier, A.; Dessen, A.; Cossart, P.; Bierne, H. Structural basis for the inhibition of the chromatin repressor BAHD1 by the bacterial nucleomodulin LntA. MBio 2014, 5. [CrossRef]

131. Camejo, A.; Carvalho, F.; Reis, O.; Leitão, E.; Sousa, S.; Cabanes, D. The arsenal of virulence factors deployed by Listeria monocytogenes to promote its cell infection cycle. Virulence 2011, 2, 379-394. [CrossRef]

132. Mungunsukh, O.; Lee, Y.H.; Marquez, A.P.; Cecchi, F.; Bottaro, D.P.; Day, R.M. A tandem repeat of a fragment of Listeria monocytogenes internalin B protein induces cell survival and proliferation. Am. J. Physiol. - Lung Cell. Mol. Physiol. 2010, 299, L905-L914. [CrossRef] 
133. Jabs, S.; Biton, A.; Bécavin, C.; Nahori, M.A.; Ghozlane, A.; Pagliuso, A.; Spanò, G.; Guérineau, V.; Touboul, D.; Giai Gianetto, Q.; et al. Impact of the gut microbiota on the m6A epitranscriptome of mouse cecum and liver. Nat. Commun. 2020, 11,1-16. [CrossRef]

134. Ansari, I.; Raddatz, G.; Gutekunst, J.; Ridnik, M.; Cohen, D.; Abu-Remaileh, M.; Tuganbaev, T.; Shapiro, H.; Pikarsky, E.; Elinav, E.; et al. The microbiota programs DNA methylation to control intestinal homeostasis and inflammation. Nat. Microbiol. 2020, 5, 610-619. [CrossRef]

135. Thaiss, C.A.; Zmora, N.; Levy, M.; Elinav, E. The microbiome and innate immunity. Nature 2016, 535, 65-74. [CrossRef]

136. Miro-Blanch, J.; Yanes, O. Epigenetic regulation at the interplay between gut microbiota and host metabolism. Front. Genet. 2019, 10, 638. [CrossRef]

137. Quereda, J.J.; Dussurget, O.; Nahori, M.A.; Ghozlane, A.; Volant, S.; Dillies, M.A.; Regnault, B.; Kennedy, S.; Mondot, S.; Villoing, B.; et al. Bacteriocin from epidemic Listeria strains alters the host intestinal microbiota to favor infection. Proc. Natl. Acad. Sci. USA 2016, 113, 5706-5711. [CrossRef]

138. Rolhion, N.; Chassaing, B.; Nahori, M.A.; de Bodt, J.; Moura, A.; Lecuit, M.; Dussurget, O.; Bérard, M.; Marzorati, M.; Fehlner-Peach, H.; et al. A Listeria monocytogenes Bacteriocin Can Target the Commensal Prevotella copri and Modulate Intestinal Infection. Cell Host Microbe 2019, 26, 691-701.e5. [CrossRef]

139. Schneider, D.S.; Ayres, J.S. Two ways to survive infection: What resistance and tolerance can teach us about treating infectious diseases. Nat. Rev. Immunol. 2008, 8, 889-895. [CrossRef]

140. Labro, M.T. Immunomodulation and infection: Back to the future. Expert Rev. Anti. Infect. Ther. 2012, 10, 245-247. [CrossRef]

(C) 2020 by the authors. Licensee MDPI, Basel, Switzerland. This article is an open access article distributed under the terms and conditions of the Creative Commons Attribution (CC BY) license (http://creativecommons.org/licenses/by/4.0/). 